\title{
THE WHITE-GRUBS INJURING SUGAR CANE IN PORTO RICO.
}

\section{IIFE-OYGLES OF THE MAY-BEETLES OR MELOLONTHIDS}

- By Eugane G. Snyт耳, Acting Fntomologist, Insulax Experiment Station.

The larvæ of all injurious Scarahaeid beetles are known popularly as white-grubs, and those occurring in Porto Rico are injurious either as grub, or as adult to the sugar-cane plant, particularly in the drier sections of the Island. An economical way of controlling these grubs is much desired, and it has been with the object of fouding some ultimate method of control that the intensive studies of the life-histories of the species have been made.

Up to the present date ten distinct species of white-grubs have been segregated and studied. Of these, four belong to the genus Phyllophaga (better known as Lachnosterna) and one to the genus Phytalus in the tribe MI elolonthini, while the other five belong to. three genera in the tribe Dynastini, which includes the large rhinoceros beetles. The present paper deals only with grubs of the first tribe, known as May-beetles, and is an aceumulation of data compiled from observations and life-history studies made by the anthor during the past four years. The work was conducted at the South Coast Laboratory, located near Guánica Centrale, which is in the heart of the district suffering most from the attack of white-grubs.

The life-cycles and habits of the five species of Dynastids will be given in another paper, to follow this.

\section{The WHTTE-GRUB ProBLEM.}

Two facts, that sugar is grown orer very extensive areas in Porto Rico, under conditions that are ideal for the development and rapid

\footnotetext{
${ }^{2}$ Especial exedit is due Mr. D. L. Yan Dine, the first entomologist of the Experiment Station of the Porto Rico Sugar Growex' Association, and lis successox, Mr. Thos. H Jones, for the initial enexgy given to the study of the white-grub problem in Porto Rico by these gentlemen. The writer wishes to acknowledge the keen interest in the progress of this work and the cooperation given by Dr. L. O. Howard and Dr. W. D. Hunter of the United States Bureau of Entomology, and by Dr. S. A. Forbes, of the Illinois State University, and thein rery efficient aid to those who bave been detailed to collect parasites in the United States. Credit is also due Dr. Robert D. Glasgow, of Illinois University, for his patience in examining the large series of Mar-beeties that have been sent him from the Island and in pointing out character's bJ which they may be separated. The writer wishes to thank Hr. John J. Davis, of West Lafayette, Indiana; for an excellent series of North American species of Phyllophaga monuted with genitalia exserted.
} 
multiplication of beetle pests of this sort, and that it is groxn continuously year after year on the same ground, without any rotation of crops, render the control of these insects a rely serious and veryr difficult problem. Prior to 1913; the year that the present studies were inaugurated, a considerable amount of experimentation had. been made by different parties toward controlling the white-grubs in cane fields, (1) by putting baits, poisons, or fumigants into the soil, (2) by spreading various deterirants on the soil near plants to prevent laying of eggs, (3) by flooding the land with water, or (4) by killing the adult beetles by means of poison sprays applied to the foliage. The results of many of these experiments were negative; and such of them as gave promising results proved inexpedient because of the high cost of materials or of application.

It became increasingly apparent that no hope of a solution of the problem could come from an application of direct methods of control such as these, but that real benefit to the cane-growring industry could come only through the employment of broadly ontlined cultural methods of control, based upon an accurate knowledge of the insects' life-histories, or perhaps through the introduction of insect or fungus parasites to prey upon the white-grubs.

Lifé-history and close field studies of the several species were instituted in May, 1913, and have been contimued to the present date. The object constantly in mind has been to determine aceurately the length of life-cycles; the time and conditions of oviposition of the eggs; the time of emergence, sexual habits, feeding habits, and habits of flight of the adults; and the inter-xelation of these habits and the factors which tend to hasten or retard the time of emergence of the beetles or to affect the amount of damage.

A preliminary report by the author appeared in the Anmual Report of this Station for the year 1913-14 (23) ${ }^{1}$ and some additional data in the Report for 1914-15 (24). Much of this data is included in the present paper, together with tabulations and graphic charts showing life-cycles, and illustrations showing injury, the enrly stages, adults and adult parts, parasites, ete., from original photogipaphs.

Methods of control of. white-grubs, and results of the introduction of parasites, will be discussed at length in a later number of this publication, when certain experiments and tabulations now in progress will have been completed. Detailed studies of the larval (or grub) and pupal stages, now being made, by which it is hoped

"Reference is made by number to "Literature cited," pp. 88-89. 
that these stages of the different species may be as easily separated as are at present the adults, will also be presented in another article.

The desire at present is to present the life-cycles of the Porto Rican Melolonthids; to facilitate the separation of the adults of the species, where heretofore they have been hopelessly confused; and to present certain facts in regard to their insect, fungus and bacterial enemies that have come to light in the comse of experiments.

\section{What WiHTTE-GrubS ARE.}

All beetles pass through a metamorphosis consisting of four stages, egg; larva, pupa, and adult, two of which, egg and pupa, are resting stages and the other two, larva and aduit, active stages. The growth of the insect is attained during the larval stage; which means that during this stage the most food is consumed, and hence the most damage committed. It is with the larval stage of the May-beetles and "hard backs," known locally as "caculos," that we are concerned. During this period they gain the name of white-grubs (or "gusanos blancos") through their white color, and their labit of grubbing in the soil.

As the term is used in its broadest sense, white-grubs are considered as including the larra of all the injurious Lamellicorn beetles of the family Scarabaeidae (3). The word is often used in the United States in a more restricted sease, as referring to the grubs or larve of the May-beetles, since these in the States far outnumber all other white-grubs combined (4).

White-grubs may be known from larva of other beetles by the following characteristics: (1) subterranean habits, living entirely in tunnels in soil or decaying vegetable matter, and moving a.bout very little; (2) by having the body bent roundly toward the ventral side, so that the ends nearly meet, hence poorly adapted to movement above ground; and (3) by their bodies being thick, soft, and usually glossy white or yellowish with sparse hairs, with a brown, chitinous head and strong mandibles adapted for chewing roots and soil, and with six well-dereloped legs not used for walking.

\section{WhITE-GRuBS INJURTous IN OTHER REgToNs.}

Larvæ of Scarabaeid beetles are practically miversal in their occurrence as pests, being everywhere known as white-grubs. They are particularly destructive, and often multiply in alarming numbers, in parts of the world where cane is grown, due to conditions which greatly favor their development in such localities. Besides Porto 
Rico, they have attained great prominence as pests of cane in the islands of Mauritius and Java, and on the continent of Australia.

White-grubs of the genus Phyllophaga are best known as pests to crops in the. United States, being widely distributed and having a great many species. As many as forty-two species have been recorded from the single State of Illinois, most of them injurious (8). Damage of the grubs to grass lands, lawns, corn, potatoes, and other crops is often very extensive (4), and the adults have been known to defoliate the timber over whole counties (5, p. 270).

A beetle known as Ligyrus rugiceps is a bad pest of cane in Touisiana, having the habit of boring into the stalks at the surface of the ground. In irrigated sections of the Southwest the large green "June bug," Allorhina mutabilis, whose larra is a white-grub, does very great damag'e to fruit.

In Enrope members of the genus Melolontha, which is closely related to Phyllophaga, have been known for over a century as pests, the grubs of one species (Ml elolontha melolontha) frequently causing so much damage to cultivated crops as to necessitate the gathering of the grubs from the fields by hand. In Russia great damage is caused by both grub and adult of a beetle lnown as Aniseplia anstriaca (13).

In Australia several white-grubs of the same tribe (known as Melolonthini), notably of the genus Lepidiota, are the cause of great injury to cane. As much as a shilling a pint has been paid for the grubs from cane fields by the sugar centrals of Queensland. The principal pest is known as Lepidiota albohirta (11).

Five species of white-grub, representing five different genera, are injurious to sugar cane in Java; namely, Holotrichia helleri, Adoretes compressus, Apogronia destructor, Leucopholis rorida, and Lepidiota stigna $(10 ; 14)$. Trap lights for the adults are used at night.

Various species of the genera Anomala and Adoretes are destructive in the Hawaiian Islands, in Japan, and in British East Africa.

In the cane-growing sections of India the roots of the plant are stibject to attack by white-grubs that are the larva of a beetle known as Sorica assamensis. Other species of white-grmbs have also been reported as injurious in India:

Among island possessions, next to Porto Rico, perhaps the most acute injury to cane by white-grubs has been committed by a species known as Phytalus smithi in the islands of Barbados and Mauritins. The adult of this beetle differs but slightly from species of the gemus Phyllophaga. The species is becoming particularly bad in Mauritius, because of its having been introduced there from Barbados without 
the wasp parasite, Tiphia parallela (2), which in the latter island tends to hold it in control. To illustrate its abundance in Mauritius (where for a while it threatened to paralize the sugar-cane industry). in a period of nine months, from August, 1911, to April, 1912, a total of twenty-seven and one-half millions of grubs, pupæ, and adults (mostly adults) were collected from the sugar-cane fields over an area scarcely three miles square surrounding the Botanic Garden (6).

In the West Indies, aside from Barbados and Porto Rico, cane is known to be injured by a species of Phyllophaga in Antigua (26) and. by grubs of Phyllophaga pativelis in St. Kitts (22). The aduits of $P$. patens are said to be very destructive to cacao foliage in St. Tincent (19). A bulletin of the American Museum (15) lists 24 species of Phyllophaga and 2 of Phytalus from the West Indies, 13 of which are credited to Cuba and 4 to. Haiti, but none to Porto Rico.

In British Guiana a beetle known as the "small black hard back," Dyscinetus bidentatus, which is the adult of a white-grub, is considered a bad enemy of cane, and a related species, ligyrus ebenus, is occasionally injurious (16). Like the Ligyrus rugriceps of Lotiisiana, it is the adult stage in which damage is done by these two beetles. Dyscinetus. sometimes attacks joung cane shoots in such numbers as to kill them back as fast as they germinate.

\section{EIFE-HISTORY WORT ON WHITE-GRUBS DONE ELSETHERE.}

Because of their subterranean liabits, white-grubs are among the most difficult of insects to rear to maturity and to gain any definite lnowledge of their changes, or molts. Outside of Europe, prior to 1916, very few species had been reared to maturity and their lifecycles determined. As late as 1913, a bulletin of the U. S. Department of Agriculture (4), in discussion of the genus Lachnosterna (Ployllophaga), stated: "There is only one published record, involyjug $\ddot{a}$ single species, in which an individual belonging to this genus has been reared from egg to adult." Since that date, however, considerable breeding work has been done in Indiana by Mr. J. J. Daris, of the U. S. Burealz of Entomology, to whom credit is due for having successfully reared to maturity from the egg eighteen species of the genus, definitely establishing the length of life-cycle of each (5).

In Australia similar difficulties have confronted investigators in this group of insects. In a bulletin of the Burean of Experiment Stations of Queensland published in 1914 (9), it is stated: "At first rearing was depended upon to give us evidence of the entire period of development, but we have not as yet succeeded in rearing a single 
specimen through its stages, but may suceed in doing so by the time the next beetle season arrives."

Ontside of Europe, and the work done by Mr. Davis in Indiana, the nearest approach to accuracy in establishing the length of lifecycle of a beetle of the group Melolonthides is the work done in Mamritius on Phytalus smithi by Mr. d'Emmerez cle Charmoy (6). He determined the maximum and minimum number of days required for each stage of the life-cycle, but did not determine the length of separate instars of the grub.

So far as known to the writer, nothing has been published heretofore on the larva of Phyllophaga or related genera which establishes accurately the lengths of instars of the grub.

\section{LIFE-CYCLES OF WHTTE-GRUBS.}

It has been known for a number of years that the common cockchafer of Europe, Melolontha melolontha, whose grub is the worst white-grub pest of that continent, required a period of three years to pass its life-cycle in the latitude of France and southern Germany, and four years in the latitude of northern Germany.

In the United States it has been taken for granted that eertain common species of Phyllophaga, such as $P$. fusca and $P$. fraterna, because of the regular periodicity of their appearance in numbers every three years, require that length of time to pass the life-cycle (7). Certain other species in the States, appearing regularly at intervals of two years, were supposed to require that length of time to undergo the change from egg to adult (33). Very recently Mr. Davis has definitely ascertained that out of eighteen species of Phyllophaga reared from egg to adult in the latitude of central Indiana eleven of them have an invariable three-year life-cycle, one (Phyllophaga: tristis) has an invariable two-year life-cycle, three have a life-cycle varying from two to three years, and two others a cycle varying from three to four years (5).

The establishment of the fact that all fom Porto Rican species of. Phyllophaga, as well as the single species of Phytalus, require but a year or somewhat less to mondergo the life changes, will be somewhat of a surprise to students of this group of insects. Yet it is what should be expected in a tropical or sub-tropical climate.

These facts are paralleled, in a measure, by those established by Mr. De Charmoy with regard to the life-history of Pleytalus smithi: in Nauritins-with the difference that he found the life-cycle of that species to occupy somerwhat orer a year (6). 
The natural enemies of white-grubs fall into three classes, namely, animals (including birds and lizards), insects (including mites and worms), and plants (fungus and bacterial). A noted French naturalist has said of the common European white-grub that "efficacious animal parasites of the insect are unknown" (29).

Fortunately, in Porto Rico, all three groups of parasites are present; yet as all of these are insufficient to keep white-grubs in check, it is necessary-when other means of control fail-to supplant these, or rather assist them, by the introduction of parasites not already occurring here.

ANIMIAL AND BIRD ENEMTES OF GRUBS IN PORTO RTCO.

There are in Porto Rico no small mammals known to prey extensively upon white-grubs or May-beetles as do skunks in the United States. Perhaps field mice and rats eat occasional specimens, but as an agency of control they can be of no great economic importance.

An attempt was made in 1913 by one of the sugar centrals of the Island to introduce and acclimate the European hedgehog, quite a number of which were brought over from Germany for the purpose. Most unfortunately, they were liberated in a hot and arid part of the Island, so different from their native humid and shady habitat that they did not survive. In confimement they ate May-beetles voraciously when fed them, but were not seen to burrow. deep enough into the soil to reach the grubs; and it is a question if they would have proved of real economic importance as a control measure had they become successfully established.

In Porto Rico insect-feeding lizards are extremely abundant. 'The, majority of these, which belong to the genus Anolis, are too small to devour the larger May-beetles. In addition they are diurnal in habit and live entirely above ground, usually upon plant foliage or trees. There is one large ground lizard, however, called "siguana" (Ameina exul), which is largely burrowing in habit and which, it is believed, feeds to some extent upon white-grubs and May-beetles. It inhabits thie sandier soils, and by one close observrer has been often seen devouring changas, or mole-crickets. Certainly, white-grubs would he far easier prey for it than the active changas; and it is altogether probable that they do constitute a part of its diet.

Of birds, there are at least three species on the Island that are important enemies of the white-grubs and May-beetles, and a fourth that is worthy of mention. These are, in the order of their importance 
as enemies of grubs: (1) the Porto Rican blackbird or "mosambique," Holoquiscalus brachypterus; (2) the bare-legged owl or "múcaro," Gymnasio midipes nudipes; (3) the little blue heron or "garza azul," Florida caerulea caerulescens; and (4) the mangrove cuckoo or "pájaro bobo," Coccyzus minor nesiotes. In Bulletin No. 15 of this Station, entitled "Birds of Porto Rico," by Alex Wetmore, the results are given of an examination of the stomach contents of these four species of birds as follows (the figures being the per cent. of whitegrub and May-beetle remains to entire contents of all stomachs examined) : blackbird, 1.61 per cent.; bare-legged owl, 24.4 per cent.; little blue heron, 1 per cent.; and mangrove cuckoo, .05 per cent. Of twenty-three blackbird stomachs collected largely in cane fields under cultivation, the proportion of white-grub and May-beetle remains to total contents was 9.47 per cent. Certainly, after a day of activity of the birds behind the plows in cane fields, the proportion would be much higher than this.

Another bird, known as the "ani," or "Juda bird," has been often spoken of as eating white-grubs; but the bulletin above refexred to does not give account of the finding of any white-grub or Maybeetle remains in stomachs of this species. And, moreorer, common as the bird is about cane fields, it is a rather shy species and is seldom seen following the plows.

The blackbird, or "mosanbique," is placed as the most important bird enemy of white-grubs because of its great abundance in those parts of the Island where the white-grubs are most injurious, namelyr in the arid coast districts. It is a very common sight to observe considerable flocks of these birds following the plows and picking up grubs when fields cleared of cane are being broken up. Figure 1 , of Plate VI, is from a photograph taken by the author at Santa Rita, neaĩ Guánica Centrale, during the winter plowing season. By actual observation and count, it was shown that over 90 per cent of the grubs exposed to light by the plows are picked up by these birds; so that the employment of peons to follow the plows and pick gruhsis quite unnecessary in that district. When it is considered that a bird is able to consume more than the equivalent of its own weight. of food in twrenty-four hours, and that blackbirds during the plowing season of five to six months subsist almost wholly upon grulss, one may appreciate the vast numbers of grubs that they consume.

INSEGT ENEMIES OF GRUBS OCCURRTNG ON THE ISLIND.

Among the insect enemies of the May-beetle larva and related white-grubs there are at least nine species known to occur on the 
Island, all native, which makes an unusually good representation as compared with other islands of the West Indies. These fall into three groups, six of them being Hymenopterous (all Scoliid), two of them Dipterous (both Tachinid), and one Coleopterous (Mlaterid). Those of the first and last groups attack only the grubs, while the Diptera attack only the adults.

We may add to these four others, all of which have been observed attacking the grubs (or eggs) under laboratory conditions only. One of them is a white nematode, not exceeding 5 or $6 \mathrm{~mm}$. in length, which on several occasions gave trouble by destroying the eggs in experimental jars. More troublesome than the nematodes was a species of minute, globular white mite (Tyroglyptus sp. ?), which attacked all stages of the beetles, from egg to adult, and was the cause of a high per cent of mortality in experimental jars and boxes.

of minor importance were a Staphylinid beetle larva (species undetermined) and a wireworm, the young of an Elaterid beetle (Monocrepidius sp.), both of which were observed to feed upon Maybeetle eggs in experimental jars. Both were introduced with earth enriched with manure, and it is not believed they would ever cause mortality of eggs under natural conditions in the field.

The following list will serve as a guide to the known white-grub parasites of the Island. The more important of them will be discussed Iater under the species they attack.

\begin{tabular}{|c|c|c|c|c|}
\hline No. & FAMILY & SPECTES 1 & IXABTTAT & $\triangle B U N D A N C E$ \\
\hline 1 & Scolitale & Elis sexcincto Fab. & General.... & Gommon \\
\hline 2 & & "xanthonotus Roh. & Northern ...... & "i \\
\hline 3 & " & Oampsomeris dorsuta Fab. ... & General........ & Abundant \\
\hline 4 & " & trifaciatse Fab. & Northern ...... & Common \\
\hline 5 & $"$ & pyrurre Rob.... & Southern ..... & Rare \\
\hline 6 & " & Serlia retrata Fal. . . . . . . . . & Westerm. ..... & \\
\hline 7 & Tachinida. & $\begin{array}{l}\text { Cruptomeigenia aurifacies } \\
\text { Wal. }\end{array}$ & $\begin{array}{l}\text { Northern and } \\
\text { Western }\end{array}$ & Abundant \\
\hline 8 & “" & Eutriandes jonesia $\mathrm{N}^{r} \mathrm{al} . . .$. & Western... & Rare \\
\hline 9 & 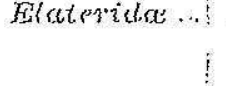 & Pyrophorits Iuminosus III. ... & $\begin{array}{l}\text { Northe'n and } \\
\text {. Western }\end{array}$ & Abundent \\
\hline
\end{tabular}

I The determinations of the wasps (except Scolia atrata Fab., which was delermined by the Am. Mus. Nat. Hist.) in this list were made by $\mathrm{S}$. A. Rohwer, of the flies by W. $\mathbb{R}$. Walton, and of the beetle by B. A, Schwarz.

The only one of these parasites which has been found hyperparasitized is Campsomeris dorsata Feb., a dead adult of which was found at Santa Rita containing a single Dipterous puparium, about $5 \mathrm{mmn}$. Iong, from which issued, on . June 18, 1913, ten small Chalcidids, which haxe not been determined. 
Ontside of Porto Rico, Elis sexcincta Fab. (?) was collected by the writer in great abundance on Mona Island in December, 1913, where it ocenred on the leares of corn infested. with Peregrinns maidis. Campsomerns pyru a Roh. was taken commonly at Higueral, Santo Domingo, in February, 1914, and a few also were taken on Mona Island.

EFGIGIENCY OF WHITE-GRUB PARASTTES TN PORTO RTCO.

Our knowledge of the white-grub parasites of the Island is at present very limited, and much is yet to be done in the working out of hosts and life-histories of the various species.

Of the nine species of white-grub parasites listed above, there is direct eridence of only one of them destroying the grubs of Phyllophaga. This is the Elaterid beetle, Pyrophorus luminosus IIl., larra of which hare been fed apon Phyllophaga grubs for long periods in confinement in the insectary. Field observations of this wireworm preying upon white-grubs are still too few to make any definite statement as to its value in white-grub control. The beetle is extremely abundant in the spring and summer on the north and west sides of the Island; if true that it destroys white-grubs under outdoor conditions, its presence may perhaps account in part for the lesser injury from grubs in the sections where it abounds.

Some of our earlier notes (for the year 1911) credit Campsomeri.s dorsate Fab. with being a parasite of Phyllophaga grubs (30, p. 36). But in all cases the grub determinations were doubtful. It seems probable that the parasitized grubs in question, if not of Dyscinetus, which dosely resembles Phyllophaga in the larval stage, were of Ligyrus tumulosus Bum., whose grub is abundantly parasitized at all seasons by Campsomeris.

It may develop, with additional observation, that the two species of Elis occurring here one or both parasitize grubs of Phyllophaga in, restricted localities. Yet the strange fact remains that of thousands of Phyllophaga grubs collected in cane fields, and examined by the writer. not one has ever heen found parasitized by a Scoliid egg or larva.

THE TACHINID PARASTTES.

Our present knowledge of white-grub conditions leads to a belies that the most important and active agency in the control of whitegrulus in Porto Rico is the work of the two Tachinid flies, Cryptomeigenia aurifacies Wal. (Pl. VII, fig. 7) and Eutrixoides jonesin Wal, upon the adults. Like the Pyrophorus beetle, these flies seem 
confined to the more humid sections of the north and west coastswhich may further explain why white-grubs are less abundant and destructive in these sections than on the dry sonth coast, where there are few or no Tachinid parasites or Pyrophorus beetles. An account of the discovery of these two flies will be found on page 37 of the Second Report of the Board of Commissioners of Agriculture of Porto Rico (30). The adult and pupal case of Cryptomeigenic aurifacies Wal., which is the commoner species, are shown on Plate VII, figure $\vec{\imath}$.

INTRODUCTION OF PARASTTES.

From many observations and estimates, it is erident that the mor. tality to white-grubs from parasites in Porto Rico is very low, and that the native parasites are quite insufficient to cope with these pests, which continue to increase wherever cane is grown. The only hope in relieving this condition has seemed to be in the introduction of other white-grub and May-beetle parasites from abroad. Among the first efforts made in the artificial control of the white-grubs of the Island, therefore, were attempts to introduce foreign parasites, which it was hoped would establish themselves successfully on the new lost grubs (27, p. 52).

The logical field for securing white-grub and Nay-beetle parasites was the United States, not alone because they are better lonown there than elsewhere in the western hemisphere, but also becanse, in a large territory like the American continent, parasites have wider distribution, and necessary conditions for collection that cannot be encountered in one locality may be met in another. For convenience of handling, collection of grub parasites is usually made of the cocoon stage from the soil, and is therefore done during plowing time. Plowing time in the States shifts from south to north with the adrance of the season, thus permitting the collecting to extend over a much longer period than would be possible in limited areas.

Parasite introduction was initiated in 1911 by Mr. D. L. Van Dine, then entomologist of the Porto Rico Sugar Producers' Expeximent Statiton. His reports of the early progress of the work will be found in the First and Second Reports of the Board of Commissioners of Agriculture (29; 30).

An entomological collaborator was employed by the Board for the purpose of collecting living white-grub parasites, or parasite cocoons, in the States and shipping them to Porto Rico in living condition. The position was first held by Mr. C. E. Hood, who began work on June 16, 1911, and later by Mr. Geo. N. Wolcott. The rrork 
was continued up to October, 1914, the majority of the parasites: having been collected in the State of Illinois. During this time a. total of about 2,500 parasites (including adults, larvæe and pupæ) were received from these workers, and of these a total of about 1,000 parasites were liberated. The great majority of these were wasps belonging to the genus Tiphia. (See Plate VII, fig. 8.) In addition to the parasites sent here, a number of cocoons of Elis were sent to Mr. O. H. Swezey in Hawaii for use against the white-grubs of those islands.

Following is a list of the better known Phyllophaga parasites occurring in North America. From these it was necessary for the parasite collectors to choose those species which conld be most easily collected in numbers and sent to the Island.

\section{NORTH AMERICAN PARASTTES OF Phyllophaga LARvAt.}

1. Tiphia inornata Say.-A black Scoliid wasp of wide distribution in the States, and possibly infesting the grubs of several species of May-beetles $(7,21,35)$. It is the commonest and best-known American parasite of white-grubs. There are several related species, for the most part feebly differentiated from it. (In Europe a species called Tiphic femorata attacks white-grubs of several Melolonthids (32) ; anothex, Tiphia parallela, attacks Phytalus smithi in Barbados (18), and Dyscinetus bidentatus in Demarara) (16).

2. Elis (Myzine) 5-rincta Fab.-A common Scoliid white-grub parasite occurring in the Central States, but more local in distribution than the Tiphic. There are other species of this genus found in restricted localities.

3. Ophion bifoveolatum.-An Ichneumonid wasp that parasitizes white-grubs, but is far less common in most localities than the Scoliid wasps.

4. Pelecinus polyturator.-A Proctotrypoid wasp, the female of which has a very long body, as if for penetrating the soil for oviposition. It has been reared by Professor Forbes from May-beetle larve and, being rery abundant in timber land in some districts of the Middle West, waay be a more important enemy of white-grubs than is generally known.

5. Sparnopolins fulvus Wied.-A small Bombylitid fly parasitic upon white-grubs, of only secondary importance, however.

6. Promachus vertebratus Say.-A large Asilid fly, larvæ of which are predacious upon white-grubs. The species is said by $M x$. J. J. Daris (5) to be a prominent grub enemy in certain parts of Wisconsin. A nearly related species in the East is Promachus fitchï O. S. 
7. Murophthalma disguncta Wied. Megaprosopis michiganensis).-A large Tachinid fly parasite of white-grubs, said to be common in the Central Western States. Mr. Vassiliev reports the same Tachinid as parasitizing the grubs of Anisoptia anstriaca, and three other species, in southern Russia (32). Another closely related species in the States is Microphthalma pruinosa, also of wide distribution.

8. Mochlosoma (Prosena) lacertosa V. d. W.-This large Dexiid Aly was reported by J. H. T. Townsend as issuing in great numbers: from the puparia in the soil in pasture lands near Colonia García, Chihuahua, northern Mexico, and he was certain they were parasitizing white-grub (29). The determination of the fly was made by Doctor Coquillet. (A related species, Prosena siberita, attacks grubs of Adoretes compressus in Java.) (10).

9. Ptilodexia (Estheria) tibialis Desv.-Another Dexiid fly, which Davis mentions as parasitizing white-grubs in Texas (5, p. 271).

10. Pyrophorus sp.-An Elaterid beetle, very abundant in southern Texas, the larvæ of which are predacious upon a common whitegrub of that section.

\section{PARAsITES OF THE ADULTS.}

11. Pyrgota undata Wied.-An Ortalid fly, the commonest and - most efficient parasite of adult May-beetles in the Central States, and also generally distributed. Another species, more local in habitat, is Pyrgota valicla Har. These are nocturnal in habits, as are also the following Tachinid flies.

12. Cryptomeigenia theutis Walk.-A Tachinid fly quite commonly infesting the bodies of adult May-beetles in some sections of the United States. The only other representative of the genus known to the writer is the common Porto Rican species, Cryptomeigenict aurifacies Wal.

13. Eutrixa exile Coq. (Nemoraea masuria Walk.)-Another Tachinid fly parasitizing May-beetles. It has habits like the preceding, infesting the beetle body.

14. Biomyia Lachnosternae.-This Tachinid, identified by Mr. Walton, is the one referred to by Dr. Forbes as Viviana sp. in Bul. 116 of the Illinois Agr. Exp. Station, according to Mr. J. J. Davis (5). It was reared from the adult of Phyllophaga crenulata.

15. Sarcophaga heticis Towns.--This Sarcophagid fly was reared from adults of Phyllophaga archata collected at Washington, D. C. 
Simultaneous with the introduction of insect parasites of whitegr'ubs into Porto Rico, Mr. Van Dine initiated an attempt to introduce certain entomogenous fungi that are knowa to attack whitegrubs and beetles related to the May-beetles in other regions (27; 29) Cultures were received both from Europe and from Hawaii, the species of most importance from the former place being Botrytis tenella (or Isaria densa), which is reputed to have been used with so much success at one time against the larvæ of Melolontha in France $(29$, p. 42$)$.

From cultures received from Hawaii one species, that known as the Samoan fungus, or green muscardine fungus, Metarnizinm anisopliae, was succeessfully established on the Island, and large numbers of May-beetles were infected by means of soil inoculations (29) (S.e. Pl. IV, figs. 7, 8, 9.) It was later learned that a local form of this fungus had already existed on the Island prior to the introductions from Hawaii, as grubs and beetles infested with the tungus were found in parts very remote from where liberations of spores had been made $(12 ; 30)$.

Several liberations of the spores of Metarrhizinm have been made by the pathologists of the Station, Mr. J. R. Johnston and Mr. J. A. Stevenson, the spore material having been grown in large cabinets on a scale surpassed only by the extensive liberations of Metarrhizium. against the frog-hopper in Trinidad. The results of these liberations have been somewhat variable (25).

\section{Method of Rearing Grubs.}

- Because of their subterranean habits, white-grubs are rery cifficult to rear to maturity, and to observe their molts. Living in tumnels in the soil, they are apt to be injured or set back in growth by being: disturbed. Difficulty rests also in their requiring so long to reach maturity, their life-cycles in many cases covering a period of more than a year, which promotes the possibility of their succumbing to fungus and other diseases contracted through artificial means.

It is possible that the difficulties of rearing white-gumbs in con-" finement are less felt in the tropics than in temperate climates becanse of there being no period of cold weather through which the grubs must be given special care and treatment. This advantage; however, is in part counteracted by the increased activity of certain parasitic fungi and other diseases that attack the grubs in wrarmer climates. 
Perhaps the most careful methods of rearing grubs in temperate climates have been worked out by $\mathrm{Mr}$. J. J. Davis at Lafayette, Indiana (5). His method consists, briefly, in the use of flower pots twelve to sixteen inches in diameter and height, or of cylinders made of metal and wire sereening, twenty inches in diameter and two and one-half feet in depth, which are inserted into the ground in such a way as to give natural conditions of moisture and drainage. Necessarily eages such as these, even though each many contain several grubs, require a rather large amount of space for the rearing of large numbers of grubs; and it must be remembered that only in the results from rearing large numbers of grubs can accurate data be obtained. Under tropical conditions, where there is no winter to contend with, methods requiring much less space have been found quite satisfactory and in most respects preferable.

Methods of rearing employed by the writer consisted at first in the use of flowrer pots six inches in diameter and of glass battery jars. The objection to the pots was that they required dumping of the earth in order to view the grubs, which meant disturbance and often injury to the grubs. The objection to the jars was that they allowed for no drainage, and the soil became sour, thus permitting mites and nematodes to breed. Furthermore, in glass jars grubs would seldom remain near enough to the glass to be seen, so there was no advantage gained.

In all respects the most convenient method was found in the use of two and one-half and three-inch round, seamless tin boxes, one and one-quarter inches high. One or two grubs were kept in each box, the larger grubs being kept in larger boxes. These boxes were conveniently kept in piles and tiers, and were opened and the contents examined regularly at intervals of several days to a week or more. Pupæ were examined almost daily. To prevent rust boxes were first lined with a thin coating of paraffin. Moisture was regulated not by adding water to the box, which experience proved was dangerous, but by using sifted earth of the right dampness to begin with, and renewing the earth when it became dry or soux.

Food was supplied by adding a kernel of corn to each box. A new kernel was never added until the old one had been entirely consumed, germinating roots and all, as it was found that greater dangex came from over feeding than from under feeding. Too much food in a box always led to an accumulation of mites (Tyroglyphus sp. ?), which would attack and often sicken the grub, finally causing its death unless the mites were carefully brushed off and fresh earth supplied. In absence of corm, a small section of cane conld be fed; 
but cane quickly soured and nearly always gave rise to mites, so that use of corn was preferable.

Movements of the grub in a can have a tendency to pack the earth, so that by careful manipulation of a knife blade the top earth may be removed and the grub's tunnel exposed. A tunnel averages three to four times the length of the grub's body; and when one part of the tunnel is opened the grub rushes to the other extremity, so that there is small danger of injury. The grub may thus be viewed without disturbing it to any great extent.

When a grub is first added to a can, the latter is filled even full with sifted (not too fine) moist earth, and with the thrumb or fing'ex a pit is compressed in the soil, into which the grub is placed. It is never covered with earth.

There is little to be improved upon in the matter of convenience in the methods described here, provided care is taken; nor is there any more divergence from natural, outdoor conditions than would be the case in using larger boxes, jal's, or pots. Check experiments proved that there was no difference in the time of emergence between adults from grubs in tin boxes and adults from grubs outdoors, provided a grub escaped the attack of mites, fungus, or bacterial disease. The presence of these diseases in small boxes was in most cases induced by over feeding, excessive moisture, or careless handling.

Check experiments for each species were run in large outdoor rearing cages, containing a deptli of six to ten inches of earth in which was grown cane or corn as food. Cages were of uniform size, three by six feet and three feet high, screen covered with wooden bottoms, set up on posts as protection from ants and rodents. Adults were usually liberated in them in quantity; one species in each, at about the same time that other series were confined in jars for eggrs. After a week or so of confimement adults were removed, eggs having' been deposited in the soil. The cage remained undisturbed, except to be regularly watered and occasionally replanted to fresh cane or corn, until sufficient time had elapsed for grubs to mature and adults to isste.

In these cages the time required for emergence tallied very closely with the time required for grubs confined in tin boxes, showing that soil conditions in the smaller tin boxes did not change the time of emergence from normal.

In the case of one species, Phytalus insularis, no larvæ reared in tin bozes were successfully brought to maturity, so that results obtained 
from the large outdoor cages were depended upon in determining the length of the life-cycle.

OVIPOSITION AND HANDLING OF EGGS.

Some difficulty was experienced in determining the possible duration of oviposition by female adults. When beetles were confined "en masse," that is, a number in a cage or jar, there was usually a heavy mortality, which may have been due to the fungus disease, Metarrhizim, being able to communicate itself from one beetle to another.

The obstacle to confining females singly for oriposition may be realized when one takes into account the difficulty of giving the heetle sufficient living food material and freedom of movenent, and at the same time restricting the amount of soil to a quantity not too large to sift and examine in a reasonable length of time. Beetles had to be confined in numbers, and the earth examined at frequent intervals, to give oviposition records value.

At first beetles were confined over potted plants; but it was found too difficult to extract eggs from among roots without crushing them. Also, the effort of supplying a fresh plant for each beetle at each examination of the soil was considerable.

Later experience showed that a beetle requires neither to fly nor climb in order to maintain a fairly normal existence in confinement. A method devised was to confine each female in a small glass battery jar, four inches in diameter by six inches high, in the bottom of which was placed two inches of moist earth, sifted to a fineness somewhat smaller than the size of the eggs, so that the latter were easily sifted out. The soil was packed lightly with the hand, and a few strips or sections of banana leaf put in above the soil as food for the beetle, being first dipped in water, after which they remained green for two or three days and were relished by the beetles.

It was not found necessary to confine adults in pairs in order to secure fertile eggs. There was no advantag'e in doing so, as copulation never took place to the writer's knowledge in small jars. Beetles collected immediately following copulation remained fertile for two months or more. No cases were observed of infertile eggs from females confined alone, except those from reared females, which of course had never copulated.

The first method devised for rearing the eggs was to place each one in a small pit made with the head of a mateh in the flat side of a small ball of damp soil or mud, and to press a tier of these 
against the glass on the inside of a jar, around the circumference of the bottom, so as to expose the eggs to view. The space was filled in with sifted soil even with the tops of the earth balls, another tier added, and so on until all eggs of a lot were placed. Corn was not planted then until all eggs had hatched, as otherwise the ger. minating roots grew into the egg cavities and smothered the eggs or. obscured them from view. Eggs were never put loose into a jar and covered with soil, as they must have room to swell, being laid under natural conditions in small cavities made by the female oripositor which allow for swelling. (See Plate $V$, fig. 9, and Plate VI, fig. 3.)

A better and simpler method was to place the eggs over damp soil in shallow glass petri dishes. Being tightly closed, and of small size, these dishes maintained the required humidity, and a great many egg's were thus easily attended to and examined in a short time. As the eggs hatched, the young grubs were removed to tin boxes. With this method, care must be taken of two things: one, that the petri dishes remain in a place of little exposure and of uniform temperature; and two, that the soil be sterile, to insure it against mites and nematodes, to both of whose attack May-beetle eggs seem to he very susceptible.

Boxes for grubs just hatched should have the soil sifted, quite moist, and packed very gently if at all. Small pits were made in the soil with a match, and the grubs placed into these; if placed on the surface of soil they are often unable to penetrate. No planting of corn was required in the boxes until grubs were nearly ready to molt, as very young grubs were observed to feed almost entirely upon organic matter in the soil, and seldom to touch roots.

\section{PUPAE AND EMERGENCE OF ADULTS.}

Before pupating, a May-beetle grub assumes a soft, flabby condition, during which it lies inertly on its back at the bottom of the tunnel. This is known as the prepupal stage. Prior to changing to the prepupa, the grub shortens and somewhat broadens its tumnel, making it very hard and smooth on the inside. In the cell so formed it undergoes the change to pupa and then to adult.

Whenever possible, it was found preferable to leave the pupa in its aatural pupal cell, simply making an opening in the top of the cell through which it could be viewed. The ase of the shallow tin boxes made this possible. When necessary, however, a smooth artificial cell open at the top was made in the soil in a tin box, and 
the pupa placed in it on its back. Soil during the pupal stage must be kept uniformly moist, and mites must be guarded against.

In the field, pupation takes place usually at a depth of one and one-half to two feet, which is a foot or more deeper than the larva lives, and this going to a lower level is attributed to an instinct on the grub's part to avoid changes of temperature, and disturbances of the soil by plowing, that would take place nearer the surface. Tt seems, however, that it is simply a provision to so place the pupal cell that the inactive pupa will not be crowded and eventually swothered by the penetration of roots into the gell, which would undoubtedly take place near the surface of the soil in a field. Grubs in the tin boxes showed no discomfort at being prevented from penetrating to a depth in the soil.

The freshly issued adult (Pl. IV, fig. 6) was left in the pupal cell in the box for several days, to observer its changes in color in reaching maturity. In a week's time or less, before the beetle had shown a desire to leave the cell, a round disc of blotting paper was snugly fitted into the box over the earth and cell, and the box was buried, with lid removed, under several inches of damp earth in a jar or pot, the earth packed somewhat, and a cover or cage put over the top in order to determine the date of emergenee from the soil.

\section{Spectes of Porto Rican Mlglolonthidis.}

All five species of Porto Rican Melolonthids that have been segregated and studied are new to science. The four indigenous species of Phyllophaga, or May-beetles, are being described by the author under the names Phyllophaga vandinei, $P$. portoricensis, $P$. guanicana and $P$. citri, and the single species of Phytalus under the name Phytalus insularis.

The characters which distinguish the species are sufficiently marked to readily separate them from allied species occurring on the neighboring islands. In the present paper will be given only the more important characters necessary to distinguish one species from the other.

As the four species of Phyllophaga fall naturally into two groups, readily distinguishable by size and other gross characters, and as the two species of each group are restricted to well-defined geographic areas on the Island, one can almost with certainty determine the species by the locality in which it was collected, lnowing the appearance of each group. The males of the four species can be separated by the characters shom in figures $4,5,6$ and 7 , of Plate $V$, 
which illustrate the male genetalia viewed from the left side. The characters of the female genetalia are less well defined in the two species of either group, but those of the two groups are quite distinct in appearance, as is shown by figures 8 and 10, Plate $V$, representing one species of each group.

The species Phytalus insularis conforms with the described character separating the genus from Phyllophaga. This consists in the tooth of the tarsal claw being situated near the end of the claw, and directed at an acute angle instead of at an obtuse or right angle to it, making the claw what is termed "cleft." This character is more or less variable with other species of Phytalus, but holds good in the case of $P$. insularis and $P$. smithi Ar.

A notworthy fact is that all of the Porto Rican Melolonthids, including Phytalus, in common with the species from neighboring islands, possess certain marked characters not ocurring in the species from the mainland which have been examined. This would seem to set them apart as belonging to another genus. These characters consist in: (1) the presence, on the inner posterior angle of the femora of the hixd pairs of legs, of a longitudinal row of promiment, stout, rather blunt spines, varying usually from three to five in number, and below each spine a long bristle-where in the species of the continent this angle is bare of spines and has few, if anyr, bristles; (2) the constriction of the transverse, sub-median ridge on the outer face of the back tibiae, which in American continental species is directed downward and bears a prominent row of bristles, or slender spines, into an anterior and a posterior flattened spur, the former bearing from three to five bristles and the latter from one to four bristles; and (3) in the presence, above the posterior flattened spur and less than midway between it and the base of tibia, of another flattened spur, bearing from one to three bristles-which in continental species is indieated, if at all, by no more than a slight eleration above a pit bearing one bristle. Occasionally, in Insular species, there is a third flattened spur above this last, having one to two bristles.

These characters of the rear tibiae occur in the West Indian species of Phytalus as well as in Phyllophaga, and make it appear that the West Indian species of Phyllophaga are a link between Ploytalus and the Phyllophaga of North America.

\section{CHARACTERS IN THE GENTTALIA.}

It is well known that many species of Phyllophaga of the American continent are practically indistinguishable from external char- 
acters, and that it is necessary to extract and examine the genitalia in order to separate them. The same is true of Porto Rican species, especially as.regards closely related species in either group. Of the two sexes, the genitalia of the male are the more highly specialized, and therefore of greater use in separating species.

The genitalia of a male Phyllophaga may be described as a semichitinous, tubular, protractile organ whose distal end, for about onet third of the entire length, is enlarged and modified into a collar, or theea, which is parted longitudinally on the rentral side. The theca is articulated at the sides to the upper or proximal portion of the genital organ, the dorsal suture being protected by a tympanum. The distal margin of the theca is nearly circular and cuplike, concealing the fleshy phallus; the ancipital margins on the ventral side are variously modified into corneous hooks or barbs. In many American species of Phyllophaga, including such species as hormi, ilicis and bipartita, the theca is greatly modified, becoming articulated on the dorsal side and formed into two highly specialized claspers, which are dissimilar in shape. In other species, such as quercus, rubiginosa and forbesi, the theca is bilaterally symmetrical and more regular in shape, as is the case rrith Porto Rican species. In none of the American species, however, is the phalins (which may be known as the median lobe of the genital organ) highly specialized as in the species, of the Island.

The median lobe of the male genitalia of Porto Rican species bears, normally, a superior, deflexed, acicular process, or spicula, which is roundly bent toward the right, and an inferior pair of adnate, falciform armatures, which cross scissor-like at their bases and recross, or at least meet, at their tips. (See Pl. V, figs. 6 and 7.) In the group including the two species of smaller size (guanicana and citri) the adnate armatures are fused into a single spatha, which is in one case fleshy (guanicana) and in the other case chitinous (citri). In the group including the two larger species (vandinei and portoricensis) the adnate armatures are distinct, chitinous, dark brown and sbining; the dextral armature superior and the sinistral inferior; they are compressed or cylindrical at their bases and depressed at the tips, which lie one over the other. The distinguishing characters lie in the structure of the tips of these armatures, which are bicuspidate in one (vandinei) and spatulate in the other (portoricensis).

The female genitalia consist, in American species, of two pairs of flattened plates, an inferior and superior, the latter extending beyond the former, and above the superior plates, at their suture, $\mathrm{f}$ 
pubic process of varying form, which is often lacking or concealed. The inferior and superior plates are often fused together. Among Porto Rican species this seems to be the case, and the pubic process is visible only in species of the larger group (vandine $i$ and portoricensis).

The following key will serve to separate readily the five Porto Rican Melolonthides:

REY TO PORTO RICAN NELOLONTHIDES.

A. Theea of male genitalia cyanthiforn, closed ventrally. Phytalus.

B. Theca of male genitalia collar-shaped, open ventrally. Phyllophaga.

a. Achate armatures distinct and chitinous; spicula medial; female genitalia with prominent pubic process. (Group of larger species.)

I. Armatures bicuspidate at tip; spicula sharply cleflexed. $P$. vondinei.

II. Armatures spatulate at tip; spicula roundly defiesed. P, portoricensis.

b. Admate armatures fused into a single spatha; spicula dextral; female: genitalia without pubic process. (Group of smallex species.)

IIr. Spatha fleshy, sumounted by minute prostrate spinules. $P$. guanicana.

IV. Spatha cymbiform, chitinous and polished above. P. citri.

\section{Phyllophaga vandinei $\mathrm{n} . \mathrm{sp} .^{1}$}

This species has been named for $\mathrm{Mr}$. D. L. Van Dine, the first extomologist of the Experiment Station of the Porto Rico Sugar Grower's' Association, who, by reason of his characteristic zeal and energy, was largely responsible for the extensive importations of white-grub parasites and for instigating the work carried on with the sugar-cane white-grubs of the Island in the past five years.

The larva of this species is the worst sugar-cane pest of the Island, and is perhaps one of the three most injurious sugar-cane whitegrubs in the world. Its habitat on the Island is restricted to the western end, its farthest east recorded occurrence being at Manatí on the north coast and at Peñuelas on the south. Within this limited territory it has reached, particularly in the Guánica district, such great abundance as to often hare caused whole fields of cane to fall prone and to begin to sour in a week's time after damage first became evident. It has made the growing of ratoon cane in the Guánica and San Germán districts impossible, and in addition to the cost of replanting for each crop, has levied a tax upon the centrals for the continued hiring of boys to collect the grubs and beetles that amounts to hundreds of dollars in a single season.

\footnotetext{
1 Technical description of this and the other species will be published later.
} 
Cases are on record where over fifty grubs of this species have been spaded out from under a single stool of cane. It is no uncommon occurrence to dig out twenty or more grubs from one cane stool. So prolific is the species that it requires constant vigilance on the part of the sugar centrals of the infested district to keep the insect in check. Boys are paid at a regular rate per quart for beetles collected on the cane foliage by lantern at night, and women are paid by the quart for grubs collected in the plowed fields in the daytime. By these means hundreds of bushels of beetles (see Pl. IT, fig. 4) and grubs are collected every season and destroyed, or fed to hogs.

Some idea of the cost of this propaganda may be derived from the following figures, available through the courtesy of the general manager of Guánica Centrale, where accurate records of the daily collections of grubs and beetles are kept:

In seven months of 1914 during which collections of beetles were - made (February 27 to September 23), the total collections in five haciendas belonging to Guánica Centrale amounted to 2,255,000 beetles, gathered at a total cost of $\$ 833.87$.

The collections of grubs for six montlas of the same year (from November 27, 1913, to May 14, 1914) amounted to a total of $1,662,000$ grubs, gathered at a cost of $\$ 1,876.73$.

In six months of the following year (March 6 to September 9, 1915), on the same haciendas of Guánica Centrale, the collections of beetles amounted to a total of $2,468,000$, gathered at a cost of $\$ 1,425.20$.

The number of grubs collected in seven months of 1914 and 1915 (from October 29 to May 27) amounted to a total of $2,425,000$, gathered at a cost to the central of $\$ 2,018.57$.

Figuring 400 beetles to the quart, and 300 grubs to the quart, this makes the rather startling figure of 369 bushels of beetles and 426 bushels of grubs collected in two years from a small district by one sugar central, at a total cost of $\$ 6,154.37$.

And still this beetle is not held in check, but appears to continne to increase in abundance. It is small wonder that the sugar-cane growers of Porto Rico have become exercised over the depredations of the "gusano blanco," as the white-grub is known locally.

THE BEETLB.

The adult of Phyllophaga vandine is a May-beetle of normal appearance, smooth and faintly shining in both sexes, but not pol- 
ished, tawny to chestnut brown in color, and varying from 17 to . $22 \mathrm{~mm}$. in length. (See Pl. IV, fig. 3.) From P. guanicana or $P$. citri it is at once separable by its larger size, lighter color and smoother surface. From $P$. portoricensis it is distinet in being confined to a different habitat, as well as by the characters cited in the preceding table.

Unlike most species of Phyllophaga, vandinei may be found in some abundance in the fields throughout at least eight and often mine months of the year. In the Guánica district, where it has been closely studied, it makes its first appearance during the last days of February, and by the last of March is abundant, remaining so from then up until late in September or the middle of October, when it rapidly decreases in numbers; and by the second week of Norem. ber few are to be found in the fields. During the two years of 1914: and 1915, figures compiled by Guánica Centrale show that the beetles were most abundant in 1914 from the last of July to early in September, while in 1915 they were most plentiful from the middle of April to early in July. These variations may be due to climatic conditions in individual seasons.

As the life-cycle of the species covers only one year, or a period of ten months for the actual egg-to-adult cycle, and as there is a possible variation (as shown by breeding experiments) in this cycle ranging from seven to thirteen months, it is evident that there must oceur an overlapping of broods, to such an extent, in fact, as to distribute the emergence of adults over all of the summer months.

THE LIFE-HISTORY WORT.

As this species is the worst cane pest of the Island, and the altimate object of all the experimental work on white-grubs was to find a practical method of controlling it, the laboratory-insectary erected for its study, and called the South Coast Laboratory, was located at Santa Rita, midway between Guánica and Yauco, in the heart of the district worst infested by this beetle. MLost of the white-grub work was put upon the one species, with the result that its habits and life-history are better known than those of any other species occurring on the Island.

More than twenty individuals of Phillophaga vandinei were reared from egg to adult, and twice as many more were reared successfully to the pupal stage. Many hundreds of egg's from confined adults were kept under observation, and the grubs hatching from them were fed and regularly observed; but a majority of these died 
before reaching maturity, some from disease or from the artificial conditions of their confinement, others from wrong handling through ignorance of the essentials for their growth. The total number of eggs, larrye, and pupæ of this species whose molts and instars were recorded was as follows: Eggs, 1,502; grubs in first instar, 852; grabs in second instar, 209; grubs in third instar, 117; pupæ, 46.

The two charts on Plate VIII show in graphic form the length of the egg to adult period of Phyllophaga vandinei.

\section{LENGTE OF LTE-CYCLE.}

The life-cycle of Phyllophaga vandinei covers, roughly speaking; one year. The average normal egg-to-adult period covers just ten months. The average from fourteen complete records of single individials xun from egg to adult was 306 days; the average obtained by adding together the average lengths of the three immature stagesthe egg, three instars of larra, and the pupa-was 302 days, The disparity is easily accounted for.

The maximum egg to adult period of the fourteen individuals was 395 days; the minimum, 212 days. Or in terms of months, they were, respectively, 13 and 7 months.

Observation has shown that the adult beetle, after issuing from the pupa, may remain in the soil in the pupal cell for a period varying from two weeks to perhaps two months. The period of preoriposition of adults was not experimentally determined, because of the refusal of reared specimens to oviposit, and the difficulty of being sure whether specimens collected in the field had just emerged or not: Calculating the pre-emergence period to average a month, and the pre-oviposition period to require close to a month, the species is seen to have a life-cycle of virtually one year.

The possible shortening or lengthening of the egg-to-adult period hy three months, which was demonstrated in rearing boxes, and which would shorten or lengthen the entire life-cycle by an equal period, gives the life-cycle of the species a proven variation of nine to fifteen months. This might be still further lengthened by the fact that the egg-laying period of the female may extend over a period of more than a month.

It is very conceivable that an egg laid quite late in the fall might not, under adverse conditions, emerge as an adult until the spring of the second year following; or on the other hand, that an egg laid in spring might, under very favorable conditions, produce an adult in the fall of the same year. This last, in fact, happened in one of 
the rearing boxes (see Plate VIII, No.1211a), although there is no way of knowing whether the adult would have emerged from the ground in the fall, under natural conditions, or would have remained in the pupal cell until the following February or March. All of which readily explains the occurrence of adults in the cane fields throughout most of the year.

THE EGG STAGE.

The average length of the egg stage, from the date it is laid to the date of hatching, was determined as fourteen days. This average was secured from a total of 1,089 eggs, the hatching of which was observed. The maximum length of egg stage was seventeen days, recorded in March, and the minimum ten days, recorded in September.

Description.-The egg of Phyllophaga vandinei is opaque and pearly white in color (in that regard resembling the eggs of other species of the gents). When first laid it is slender oblong-oval in shape, about $2.75 \mathrm{~mm}$. to $3 \mathrm{~mm}$. in length by $1.62 \mathrm{~mm}$. to $1.75 \mathrm{~mm}$. in breadth. It swells greatly before hatching, and becomes almost spherical, $3 \mathrm{~mm}$. to $3.25 \mathrm{~mm}$. in length by $2.35 \mathrm{~mm}$. to $2.65 \mathrm{~mm}$. in breadth. (See Plate MI, fig. 1.)

Eggs are deposited among roots in the soil in small globular pits, or carities, which are made by the ovipositor of the female. One egg is laid in each pit and rests at the bottom. (See Plate V. fig. 9.) The earth forming the walls of the pit is cemented or compressed in such a way that even in dry sifted soil the pits usually remain iatact, when the soil is sifted, until put under pressure of the thmmb. The pit varies from two to three times the diameter of the egg, and serves to maintain a uniform humidity as well as to prevent the soil from touching the egg. When fully swollen the egg does not completely fill the pit, so that when it hatches the grub, which is half again greater in diameter than the swollen egg (see Plate III, fig. 2), has a natural cell in whieh to move about and begin existence.

THE WHITE-GRUB, OR LARVAL STAGE.

In common with other white-grubs, the larva of Phyllophaga vandinei molts its skin three times, passing through three distinct instars. In computing the length of life-cycle the average, maximum, and minimum lengths of each instar were found.

- Of fifty larra of this species reared from egg to pupal stage, in which the exact dates of hatching of egg and of pupation were re- 
corded, the average length of larval stage was 267 days; the maximum, 356 days; the minimum, 179 days. Or, reduced to months, the average length of larval stage was about nine months; the maximum, twelve months; and the minimum, six months. It is at once apparent that the astonishing variation in the length of life-cycle of this species is due to the variation in length of the larval, or grub, stige, the egg and pupal stages showing very little variation in duration. (See charts on Plate VIII.)

Nine out of ten months (or 90 per cent) of the insect's nomal life below ground are spent in the larral, or grub, stage. During most of this time the grub is doing actual damage to cane by feeding upon the roots.

The length of larval period, secured by adding together the averages of the three instars, amounts to 266 days. This constitutes a very good check on the above average of 267 days, computed from. the whole larval stage of 50 larva, since a good many of the grubs from which the instar averages were taken never reached pupation, and conversely, a majority of the grmbs whose exact dates of egg hatching and of pupation were recorded, were not observed and recorded as to their molts; so that the two results were taken to a large extent from different series of grubs.

The explanation for fifty grubs having reached the pupal stage, whereas only about twenty reached the adult, lies in the fact that at the time of pupation the grub is particularly susceptible to injury by handling, or by attack of the bacterial disease, Micrococcus nigrofaciens Nor. (17). Nany grubs while active seemed to resist the disease, which attacked a majority of them, but during the quiescent prepupal stage they succumbed. The presence of mites on the body of a grub would often prevent its pupation, or cause the pupa to, be deformed, and the adult would not issue.

The first instar.-Technical descriptions of this and the other instars and stages of Phyllophaga vandinei will be given in a later issue of the Journal, when detailed studies have been completed. For the present, the plates may be depended upon to give a fairly accurate impression of the size and appearance of the different instars of the grub.

The average duration of the first instar was determined as 36 days; the maximum, 59 days (in December); the minimum, 17 days - (in June). The maximum duration was found to be more than three times the minimum. The duration of this, as well as the other instars of the grub, has been shown to be influenced more by the amount. of moisture in the soil, and by the presence or absence of mites, fun- 
gus or bacterial disease, than by the amount of food provided the grub. (When grubs succumbed to the Metarrizium fungus during the second or third instars, it was found that the earlier instars had been above normal in length.)

From the fact that larva of Nay-beetles are always in a coiled position, and seldom straighten out to crawl as do the grubs of Rutelids and Dynastids, it is very difficult to measure their length. It was ascertajned, however, that the length is just double the measurement across the coiled body, so that the length of grubs in the various instars was determined in this way.

At the time of hatching from the egg, the grub of vandine $i$ is about $6 \mathrm{~mm}$. long and $1.75 \mathrm{~mm}$. to $1.8 \mathrm{~mm}$. across the head. Before molting to the second instar (see Plate III, fig. 3) it reaches a length of $17 \mathrm{~mm}$. to $18 \mathrm{~mm}$., and the head reaches a diameter of $1.9 \mathrm{~mm}$. to $2 \mathrm{~mm}$. (PI. $V$, fig. 1.)

The head does not grow like the body, but that it enlarges somewhat in size may be shown by the following brief table, from actual measurements with sliding calipers from living grubs: ${ }^{1}$

HEAD OT FIRST-INSTAR GRUBS.

An average from 5 grubs parying from 5 to $10 \mathrm{~mm}$, in length; head 1.85 mun. wide.

An average from 29 grubs varying from 11 to $15 \mathrm{~mm}$. in length; head 1.96 nm. widle.

An average from 11 grubs raxying from 16 to 18 sm. in length; head 2.01 mm. wide.

During the first instar no damage is done by the grub of vandinei, since it lives entirely upon regetable matter in the soil. It is ouly during the very last days of the instar, or more commonly in the early part of the second instar, that the grub begins to eat living roots.

The second instar. - The average duration of the second instar (see Plate III, fig. 4) was found to be 47 days; the maximum, 103 days; the minimum, 26 days. $\mathrm{Or}_{1}^{2}$, reduced to months, the average was one and one-half months; the maximum, three and one-third months; and the minimum, somewhat under one month. It is seen that the maximum duration of this instar was more than four times the minimum.

At beginning of the second instar the length of the grub is $17 \mathrm{~mm}$. to $18 \mathrm{~mm}$.; at end of the instar, and just before molting to the third. instar, the length is $28 \mathrm{~mm}$. to $30 \mathrm{~mm}$. The average width of head, taken from 43 second instar grubs, was 3.33 mm. (See Plate $V$, fig. 2.)

\footnotetext{
${ }^{1}$ Notk. - Measuremexts of small objects made with sliding ealipers are rery apt to arerage from $.1 \mathrm{~mm}$, to $.15 \mathrm{~mm}$, above actual size.
} 
An idea of the enlargement in the head during the second instar may be gained by the following figures, taken from measurements of living grubs:

HEAD OT SECOND-INSTAR GRUBS.

An average from 23 grubs rarying from 18 to $25 \mathrm{~mm}$, in length; head 3.25 mm. rvide.

An average from 20 grubs parying from 26 to $30 \mathrm{~mm}$. in length; head 3.42 . mm. wide.

The third instar. - The average duration of the third instar, from records of 25 grubs, was found to be 183 days; the maximum 266 days; the minimum, 78 days. Again, the maximum duration of the instar is more than three times the miximum. Reduced to months, the arerage length of the third instar is six months; the maximum, nine montlis; and the minimum, two and one-half months.

Approximately two-thirds of the larral period is spent in the third or last instar, or about three-fifths of the entire life of the immature insect. During more than six months of the year this insect is doing great injury to erops in the soil as a grub. There being no winter in Porto Rico during which the grub is not feeding, its activity as a root trimmer extends not only through five and onehalf months of the third instar (allowing one-half month for the quiescent, pre-pupal stage), but also through the month and a half of the second instar, so that the period of injury may easily cover seven months.

At beginning of the third instar (see Plate MI, fig. 6) the grub averages about $28 \mathrm{~mm}$. in length, and when full grown (see Plate III, fig. 7) it reaches a length of $40 \mathrm{~mm}$. to $44 \mathrm{~mm}$. The average width

- of head from 96 grubs ineasured in the third instar was $5.29 \mathrm{~mm}$. (See Plate $V$, fig. 3.)

The rate of growth of the head during this instar may be seen from the following table:

HEAD OH THIRD-INSTAR GRUBS.

Average from 30 grubs varying from 26 to $30 \mathrm{~mm}$, long; head $5.13 \mathrm{~mm}$. Average from 19 grubs rarying from 31 to $35 \mathrm{~mm}$. long; head $5.26 \mathrm{~mm}$. Average from 42 grubs rarying from 36 to $40 \mathrm{~mm}$. Iong; head $5.39 \mathrm{~mm}$. Average from 5 garubs rarying from 41 to $45 \mathrm{~mm}$. long; head $5.45 \mathrm{~mm}$.

The factors which influence the rate of growth in the third instar of the 'grub are:

(1) Available food supply; i. e., contiguity of abundant living plant roots.

(2) Humidity and texture of soil. Hardness or softness of the 
soil naturally retards or facilitates the easy movements of the grub in its constant search for fresh roots. For this reason white-grubs are worse pest in friable than in heary clay soils.

(3) Temperature (time of year). The length of this instar somewhat increases, as do the others, during the winter months, though at no time of year do the grub's activities entirely cease as result of cold weather, as happens in more northern latitudes.

(4) The presence of disease in the grub. As previously stated, infection with the Metwry and growth of the grub, as does bacterial infection, thus lengthening the duration of the instar.

(5) Attack by mites, or by other dermal parasites that molest the grub.

THE PRE-PUPAL STAGE.

The so-called pre-pupal stage of white-grubs is the resting period. that occurs at the end of the third instar during which the grub is preparing for pupation. It is characterized by a puckering or gathering of the skin, general flabbiness, and a discoloration or yellowing in color (see Plate III, fig. 8). The larva lies on its back, dormant, in a rounded, oblong cell about 35 to $40 \mathrm{~mm}$. long; the body is much flattened and the caudal end rather sharply bent upward; the legs are held stiffy outward, close together, and display little or no morement. There is no molt between the third instar and the pre-pupal stage.

From two weeks to a month prior to the pre-pupal stage, the grub shows the approach to pupation by its sluggishness, by the body becoming yellow, more opaque, and harder to the touch, and by a disappearance of the dark stain at the caudal end of the body resulting from the earthy excretious matter within.

From about a dozen observations of reared grubs, the pre-pupal stage yaried from four to seren days. There was in each case an added period of about a week to two weeks during which the grub was sluggish and did not feed, thus indicating its preparation for the pre-pupa.

THE PUPAL STAGE.

When the pre-pupa molts, the pupa is at first white and misshapen; but within twenty-four hours it has assumed its natural shape (see Plate III, fig. 9; also Plate IV, figs. 1 and 2) and shiming yellow-brown color. The pupa lies on its back in the cell, and the 
orumpled molt skin (Plate III, fig. 9) remains near it, at the candal end.

The average duration of the pupal stage, from 22 observations, was 211/2 days; the maximum, 26 days; the minimum, 17 days.

From thirteen measurements, the arerage length of the pupa was $25.1 \mathrm{~mm}$., the average width $11.15 \mathrm{~mm}$., and the average breadth of the head $8.18 \mathrm{~mm}$.

A day or two before katching into the adult, the pupa turns over in its cell and lies with the back upward. In this position the aduIt is always found in the cell, never will back downward. On a pupa about to hatch the skin is wrinkled, and the white color of the elytra may be seen through elytral sheaths. (See Plate III, fig. 10.) The formation and sculpture of the legs may also be seen throngh the now transparent pupal skin.

\section{ISSUING AND ENERGENCE OF ADULT.}

An adult just issued has only the legs, head, and thorax brown, the elytra being white and soft, and the wings extended their full length beneath the elytra. (See Plate IV, fig. 6.) In a few hours the beetle turms tawny yellow in color, then gradually deepens in shade during the following week.

The term issuing applies to the breaking of the pupal skin, and the exit of the newly formed adult from the pupa; the term emergence applies to the appearance of the beetle above ground. The interim between these two periods is spoken of as the period of preemergence, and is the time spent by the newly-hatched beetle in the pupal cavity in the soil-a time rery necessary for the chitinous parts of the beetle to become perfectly hard, so that it can dig its way upward to the surface of the ground.

In many North American May-beetles the pre-emergence of adults covers a period of several months-usually from the late summer or fall of one year to the spring of the next. In the Porto Rican species this period extends rarely over five to six weeks, judging from observations.

Because of the fact that most of the confined specimens of vandine $i$ were reared in small tin boxes, in which the adults at time of pre-emergence were disturbed and did not behave normally, our records of pre-emergence are somewhat incomplete. The following notes, however, prove it to extend over a period of two weeks or more:

(I) No, 54\%,-On July 1 two adults hatched from pupae in earth in a jar, 
whicl were still alire in the cells but had not come to the surface of ground when the soil was dumped, July 30 . Time, orer 29 days.

(2) No 548,-One female and two male adults, hatched in a battery jar on July 3,7 and 18 , respectively, had not reached surface by July 30 , thougt two of them were still living. Time, over 12 to 27 days.

(3) No. 117\%c.-A female, issued Aprid 12 in a jar, had not come to the surface on April 28, though stinl living. Time, over 16 days.

(4) No. 12196.-A female hatched February 15 and had not come to surface through four inches of damp soil by Mareh 10, though still alive. Time of preemergence, over 23 days.

DISTRIBUTTON OF THE SPECIES.

Phyllophaga vandine is confined to the western end of the Island, a territory equivalent to about one-third of the area of the Island. Its eastern distribution may be defined, roughly, so fax as our present knowledge goes, by a north and south line across the lsland through the towns of Manatí on the north and Peñuelas on the south. The type of the species is from Santa Rita, near Guánica.

The analogue of this species at the eastern end of the Island is Phyllophaga portoricensis, which is indistinguishable from the former species except by means of the genital characters giren in the table. It is indeed possible that the two are but races of one species, for there seems to be a general intergrading of the characters along the geographic line separating the two species. Yet at no time have the tw wo been taken in one locality; and the specific characters are suffciently recognizable in specimens from the type Iocalities, Guánica and Río Piedras, to set apart the species as quite distinct.

FEEDING HABITS OF THE ADULTS.

All May-beetles feed upon the foliage of plants and trees, and are voracious eaters. The adult of vandine $i$ differs from many species of the genus in being a very general feeder, and there are few plants which it will not touch. Feeding is done entirely at night, the adults issuing from the ground at dark, or a little before. After a rery brief flight, they alight upon suitable foliage and begin to feed upon the margins of the leares. Feeding continues until very late into the night, the beetles appearing to be as abundant after midnight, as before. Spending thus six hours or more of the night in feeding, they consume quantities of. vegetation. Small tress of "quenepa," of "salcilla," and of mative china-berry have been found completely stripped of foliage by this species. Cane also suffers from depredations of the adults, but not to such an extent as the foliage of certain trees. A common ornamental tree of the south side of the 
Island, the casuarina, and another of general use along roads in Porto Rico, the flamboyant, are both very badly. attacked by adults of this species. Banana and coconut trees often show acute injury from their feeding. (See Plate I, figs. 1 and 2.)

It has not yet been determined at what hour of the night their feeding terminates, but it must be well toward morning, as they have been collected feeding as late as 2 a. m. Nor is it known. whether, at termination of feeding; they fly or drop to the ground. When distrurbed in feeding they drop, using the wings usually to carry them a short distance; and this is probably the method employed at the end of the feeding.

So uniformly abundant is Phyllophaga vandinet over the infested area that unusual and sporadic appearance of adults in such numbers as to cause bad defoliation in restricted areas is rare. The infestation is general, and usually heary. Cane foliage may always be found somewhat damaged in the Guanica district and the San Germán valley.

Following is a list of some of the commoner plants and trees occurring in or near cane fields in the infested area, grouped according to their attractiveness to the beetles.

(1) Those greatly relished by the adults-

Flamboyant (Poinciana regia); Australian pine (Casuarina equisetifolia); almendro (Terminalia catappa); salcilla (Schrantia portoricensis); quenepa (Helicocca bijuga); guasima (Guazuma guasuma); China-berry (Melia azedarsch); tamarind (Tamarindus indicus); jobo (Spondias lutea); banama (Mrusa sp.); coconut (Cocos nucifera); cecropia (Cecropia palmata); 勇ig-weed, or bledo (Amaranthis spp.); mallow (Malachra rotundifolia); and Petiveria alliacea.

(2) Those eaten to some extent, but not apparently as much relished as trees and plants in the preceding list-

Sugar cane (Saccharum officinamu); guara (Psidium guajava); almacigo (Bursera simaruba); jaguey (Ficus lentiginosa; bucago (Erythrina glanca); royal palm (Roystonea borinquena); encalyptus (Eucalyptus spp.) (very rarely); Jamaican sorrel (Hibiscus sabdariffa); native cotton (Gossypun sp.); Guimea grass (Panicum maximum); malojillo, or Para grass (Panicam barbinode); Casearia syluestris; and Cordia corymbosa.

(3) Those which appear to be entirely exempt from attack by the adults-

Hawaìian algarroba (Prosopis juliflora); papaya (Carica papaya); gallito (Sesbania grandiflora); gandul (Cajanus indicus); pepper tree (Schinus molle); black sage (Cordia cylindrostacha); roble (Tabebuia rigida); ealabash (Crescentia cujute); berengena cimarrona (Solanum torvum); silk cotton weed (Calotropis procera); acalypha (Acalypha uvilkesiana); Citrus spp.; and Clidemia spp. 
During the day the beetles conceal themselves by burrowing into the ground, usually near the bases of trees or large weeds. Often a dozen or more holes may be found around the base of a tree upon which they have been feeding. At night they begin issuing from these burrows at about sumdown, and their flight seldom lasts for: more than fifteen to twenty minutes.

On one occasión, in October, observations were made at sundown of a large screened cage into which had been put five hundred adults a. few evenings before. The beetles began appearing from the soil at $6: 25$ p. m., were issuing in greatest numbers at about $6: 35 \mathrm{p}, \mathrm{m}$., and had practically ceased to appear by $6: 45 \mathrm{p}$. $\mathrm{m}$. The majority took wing immediately upon making their exit from the holes, or

- crawled up a near-by weed and then took wing; a few climbed weeds and began to feed without flying at all. Nearly all flew westwardly, against the western side of the cage. The flight of the majority lasted until about 6:50 p. m.; the last of them had ceased flying by $7: 00$.

Adults of this species do not usually fly for long distances. By watching up and down a "callejón" (a bare or grass alleyway 20 to 30 feet wide) between cane fields at about dusk, in a place where infestation by the beetles was known to be heavyr, it has been noted that comparatively few of the beetles flew across the "callejon," but that the majority hovered over the cane plants very near to where they had arisen. On various occasions casuarina trees in a Bermuda-grass lawn were watched at dusk, and it was noted that the beetles usually hovered around the trees near whose bases they had made exit from the ground, but never arose high and took direct fight for more distant trees.

Another observation confimed the belief that the dispersion of yandine $i$ by flight is not extensive. In a large outdoor screened experimental cage, 6 by 10 feet in area, into which 2,000 beetles were introduced on April 2, it was observed a week later that the cane growing at the end of the cage where the beetles bad been introduced was entirely stripped of foliage, while cane growing at the opposite end was virtually untouched, showing decidedly the slow dispersion by flight.

\section{ATTRACTION TO LIGHT.}

Adults of vandine $i$ are quite readily attracted to light, as is us!nal with May-beetles. Experiments mere made with a large 500-e. p. 
Pitner gasoline lamp, with a view of finding some suitable method of taking adrantage of this fact for the destruction of the beetles. The lamp was placed on the roof of a two-story building near the insectary at Santa. Rita, and a canvas stretehed on a rertical frame was put beneath the light. Since a few individuals often come to an ordinary lamp in a room, it was cxpected that the Pitner light, with its great power, would attract large numbers. This hope was not justified, as out of twrenty-three evenings in July, August, October. and November during which the light was run, beetles were taken on only seven, a total of twenty-four being taken.

The reason for this searcity of beetles was that the Pitner light was always started about 8 o'clock, and Phyllophaga adults are ordinarily only attracted to light during their flight and before they have settled on foliage to feed (before $7: 30 \mathrm{p} . \mathrm{m}$.). To have any practical efficiency in attracting vandinei adults for destruction, a light must be close to the ground, and must be started immediately at dusk, while beetles are flying. It need not be run for over an hour after dark, as time after that is wasted. There have been cases where adults of this species and portoricensis have left their feeding on the foliage and flown to a motorcycle headlight as late as midnight ol after, but these cases are rare. Almost never, while collecting beetles with a bull's-eye light, have they been known to leave their feeding and fly to the light.

\section{COPULATION.}

This species is not often found in copulation in the field, the reason being that collecting is usually done after $8 \mathrm{p}$. m., while mating takes place before that hour. On one occasion recorded, when collecting was done between 6:45 and $8: 25 \mathrm{p}$. m. (on October 14), out of 79 adults collected on cane, "salcilla" and "malojillo," only one pair was found in copula (at $7 \mathrm{p}$. m.). Lateness of the season may have accounted for so few being found copulating at that honr.

Pairs were occasionally found copulatiog on the foliage of small casuarina tress near the insectary. Pairs thus observed on two evening's in April were recorded as follows:

(1) Copulation began before $7: 30$; ended at $7: 45$; duration 15 minutes + .

(2) Copulation began before $7: 30$; ended at 7:53; duration 23 minutes + .

(3) Copulation began before $7: 35$; exded at $7: 45$; duxation 10 minutes + .

(4) Copulation began before $7: 35$; ended at $7: 48$; duration 13 mimntes + .

(5) Copulation began before $7: 35$; ended at $7: 50$; duration 15 minutes + .

(6) Copulation began before $7: 35$; ended at $7: 50$; duration 15 minutes + .

(7) Copulation began at $7: 31$; ended at $7: 52$; duration 21 minutes.

(8) Copulation began at $7: 34$; ended at $7: 53$; duration 19 minutes. 
It is evident that copulation of this species takes place quite miformly between 7 and 8 p. m., or immediately after the cessation of flight, and that the average duration exceeds sixteen minutes. It may possibly be learned, with further observation, that the oviposition of the Tachinid parasites, Cryptomeigenia aurifacies Wal. and Inutrixoides jonesii Wal., on the adult beetles takes place during the copulation and before the total darkness of night comes on.

OVIPOSTTION OF FEMALES.

Oviposition takes place in the soil adjoining the beetle burrows at the bases of trees and plants, where the young larvæ will be inmediately among the roots. Exact depth at which eggs are laid in the soil has not been determined, but probably averages from eight inches to a foot, the depth at which beetles are usually found in their burrows.

As stated before, to secure eggs in confinement for the purpose of determining the length of the period of oviposition of females and the average number of eggs laid by a female, beetles were confined. both singly and "en masse;" and the results from the two methods did not vary much. The method of confining the females has been described on page 63. No eggs were secured from reared females, unfortunately.

The individual egg-laying records of females of vandine $i$ are graphically shown in the two charts on Plate IX. The complete records are given in the following tables: 


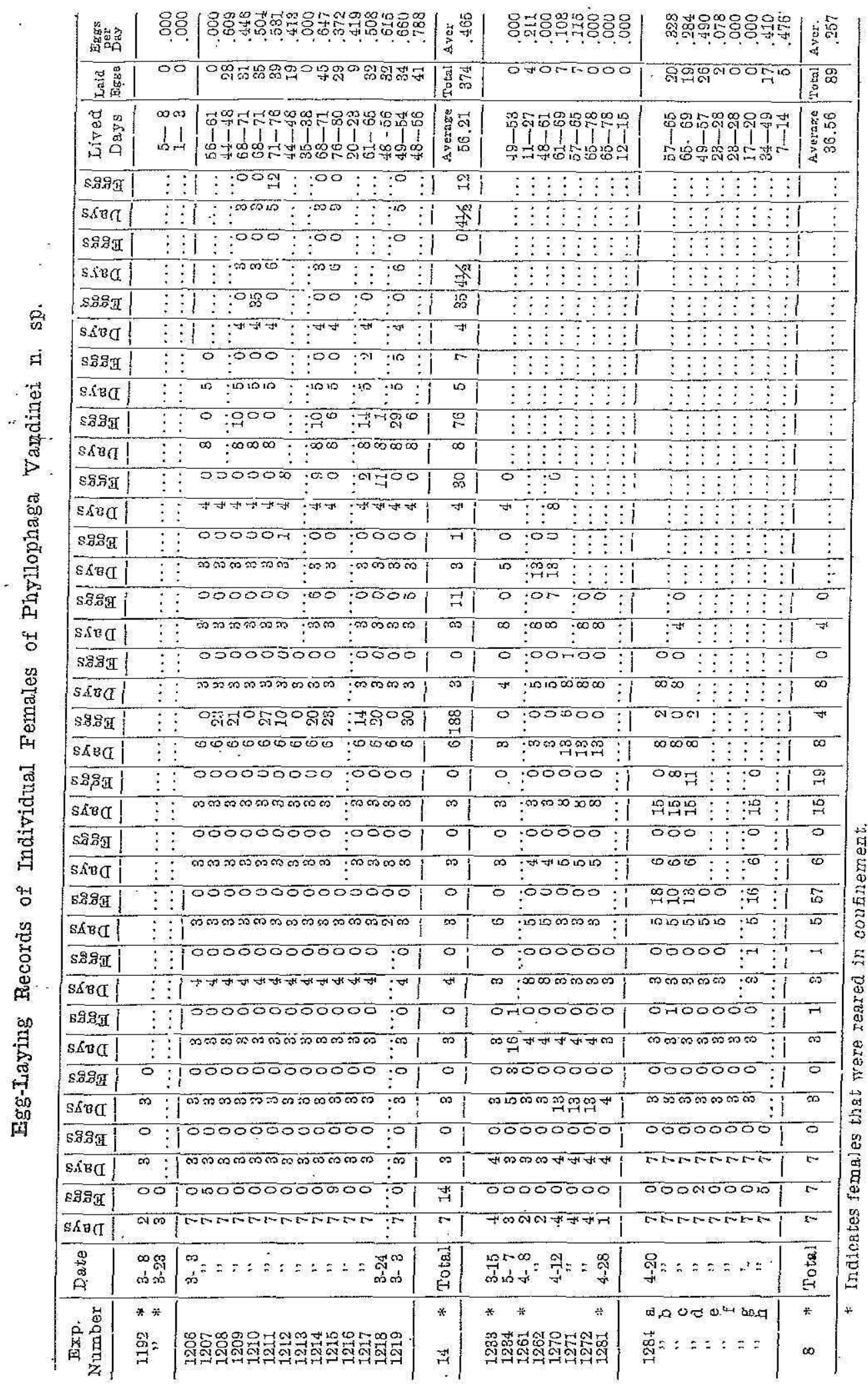




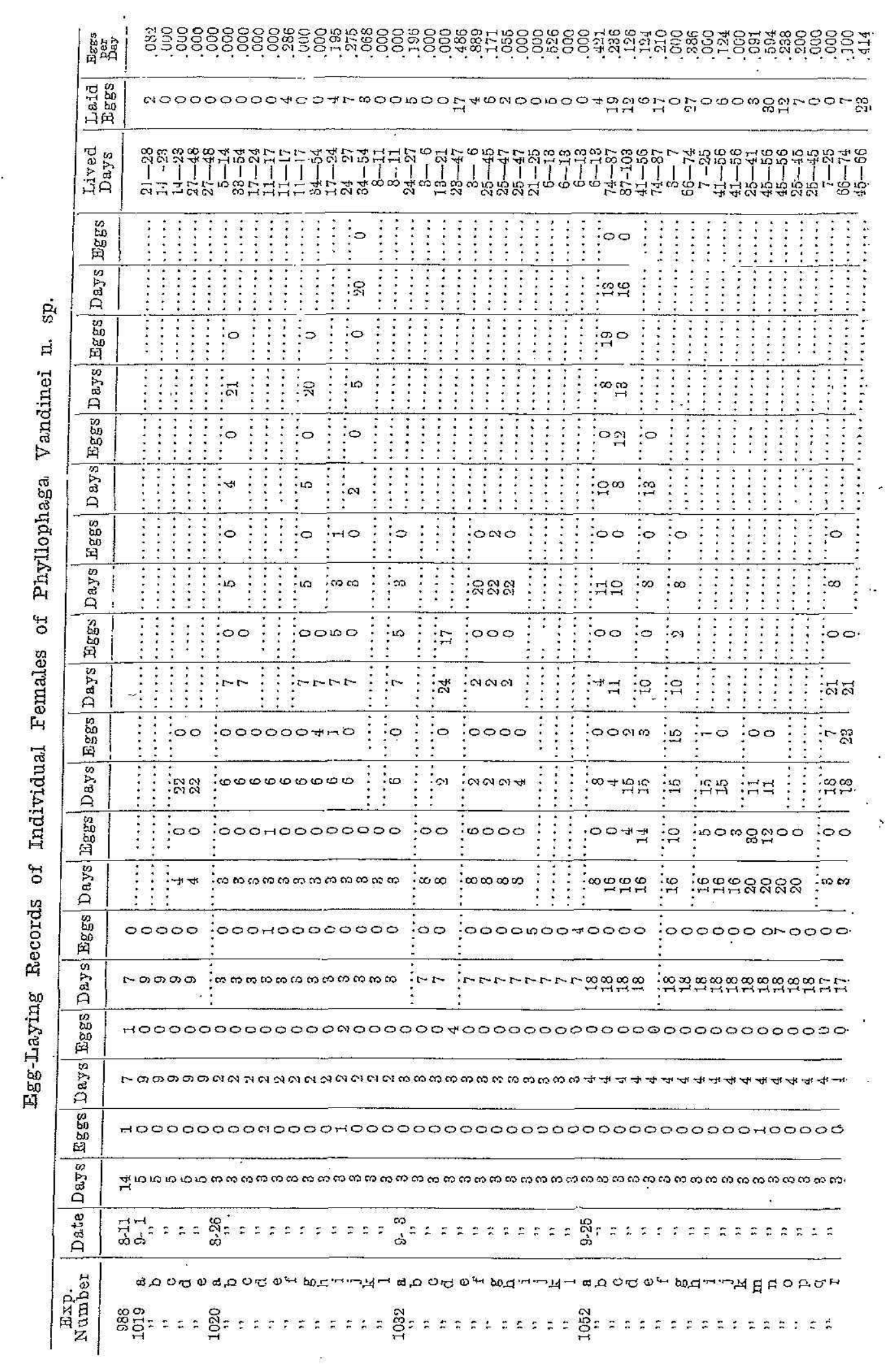


Exclusive of reared aduits, a total of 75 females were confined singly for eggs, of which number 45 females laid a total of 713 eggs, or an average of 16 eggs each, while 30 females laid no eggs.

Average from the 45 females, .345 eggs per day, or 1 egg each 3 days.

Average from the 75 females, 204 eggs per day, or 1 egg each 5 days.

It is reasonable to believe that those females which did not lay eggs were old females, and were exhausted of egos before confined. The confined females were collected in the field, and their age from date of first emergence could not therefore be determined. It is beliered that the average from the forty females that laid eggs can be taken as nearly the correct or normal figure.

The average length of life of 45 females that laid eggs was 47 days (about one and one-half months); the average length of period of oviposition 11 days (about one and one-half weeks). (The duration of oviposition is taken as including the time between the recorded dates of laying of the furst and last eggs in confinement.) As the environment of the beetles in the experimental jars was certainly quite different from that outdoors, it is possible that these figures would be materially lengthened in outdoor or natural conditions.

The greatest duration of the egg-laying period was 42 days (or six weelrs), the female laying in that time only 39 eggs, or slightly under one egg per day. The egg-laying period of 25 out of the 45 females was less than one week in duration.

The female that lived the longest in confinement, 95 days (or thirteen and one-half weeks), laid only 12 eggs, all within three days. One female lived 59 days (or eight and one-half weeks) and laid no eggs, being fed, however, during the entire period.

The egg laying of adults is periodical. For instance, in the group of 14 females included in the numbers 1206 to 1219, inclusive, where the average length of life was 56 days, over half of the 188 eggs were laid within six days-between the 30th and 35th days of confinement. Again, in the group of eight females included in the mumbers $1284 a$ to $1284 h$, inclusive, where the average length of life was $36 \frac{1}{2}$ days, over three-fifths of all the 57 eggs were laid in the five days betweem the $27 \mathrm{th}$ and $32 \mathrm{~d}$ days of confinement. There facts, merely as circumstancial evidence, would make it appear that about a month is required for mature eggs to form in the female uterus after copulation.

The largest number of eggs laid in a short space of time by a female was 35 (see No. 1209), laid in two days, or at a rate of 18 eggs per day. 
The data obtained from the females confined "en masse" show that-a total of 1,406 females laid 1,560 eggs in an average period of 6.4 days. Or, reduced to the equiralents of the preceding table of arerag'es:

Average from 60 per cent of females, .29 eggs per day, or I egg each $31 / 2$ days. Ayerage from all the females, .172 eggs per day, or 1 egg each $5 \% 4$ days.

\section{INSEGT PARASITISAT.}

The insects which prey upon this species are the same as those listed for the genus. Probably one of the more important ones is the predacious wireworm, Pyrophorus luminosus Ill., the exact value of which, however, as a control of the grub in the fields it is very difficult to ascertain, from the fact that, in digging or plowing, living wrireworms are very rarely found adjacent to the grubs they have attacked.

Other important enemies of vandinei, in the more northern part of its range, are the two Tachinid flies which parasitize the adults.

As to the large Scoliid wasp, Campsomeris dorsata Fab., it has been found that on the island of Barbados the species, though commonly parasitizing and apparently preferring the Dynastid, Ligyris tumulosus Burm., is occasionally found parasitizing a common Melolonthid, Phytalus smithi Arrow (18, p. 56). In Porto Rico this wasp is particularly abundant in the Guánica district, where it has been often found parasitizing Ligyrus tumulosus grubs. It is possible that it may rarely attack grubs of Phyllophaga vandinei; but to the present date none of the records of its attack of this species have been rerified; and the fact is patent that, of many hundreds of grubs of randine $i$ examined by the writer, and many dozens reared in confinement, not one has ever been observed parasitized by egg or larra of this wasp. Dry grub remains have been examined attached to numbers of Campsomeris cocoons collected at Santa Rita, but none of them proved to be vandinei.

The Tachinid Aies.--Two species of Tachinid fly, Cryptomeigenia aurifacies WaIton (see Pl. VII, fig. 7) and Eutrixoicles jonesii Walton, which have been previously discussed, are known to attack this species and portoricensis in the more humid parts of their habitats; and to do much to keep them in check in those localities. A rather large percentage of specimens of vandine $i$ collected at Añasco, at the west end of the Island, have been found infested with the pupæ of Cryptomeigenia, and a far smallex number with Eutrixoides. Collections of pupæ have been made in April, May and September, but doubtless can be found throughout the year. The number of pupe 
found within one dead adult host varies from two to nine, usuallyr - four to six. Infested beetles that have died are always found in their burrows in the ground.

Work on the life-histories of the two species is in progress now, but has not yet been completed.

Neither species has been found to occur in the Guánica district, where the damage from vandine $i$ is most acute. Attempts to introduce the files at Santa Rita, using infested beetles taken thele from Añasco, were not successful; and it seems probable that the flies do not thrive in a dry climate like that of the south coast.

Attucked by mites and nematodes. - In the experimental jars and boxes some difficulty was experienced in the rearing of eggs of vandine $i$ because of attack by nematodes and mites, the latter appaxeatly a species of Tyroglyphus. The following brief notes may serve as examples of the manner in which this loss of eggs occurred:

No. 1016.-Angust 25, eleren eggs, laid since Angust 17, were put into arti.ficial cells at bottom of a jar. August 26, one egg destroyed, surrounded by a myriad of young nematodes. August 27, two more similarly destroyed. August 30, all the other eggs but four clestroyed by the nematodes.

No. 1021.-August 26, fourteen eggs, laid Angust 18 to 21, were put into damp sifted earth at botton of jar. August 27, one destroyed by nematodes and mites. August 29, two more destroyed. September 30, last two killed by mites, and being eaten by them.

The injury from the mites was not limited to the eggs, grubs in all instars often suffering badly, even dying, from their attack. The following notes give specific examples of mite injury to grubs:

No. 1049d.--January 28, a grub in second, molted about December 12, heavily infested with mites. February 17, gxub died as result, without being able to molt.

No. $1049 \mathrm{~g}$-January 18, a grub in second, nolted about December 20, partly 'overed with mites on head, legs, and front of boily. February 25, molted. June 25, sickly, with many mites. Jume 30 , dead, eaten up by mites.

No. 1193.--May 3, grub preparing to pupate put into box. May 22, died before pupating; covered with mites.

No. 1216a.-May 15, grub in first, hatebed May 15, has mites. June 2, injuxer by mites, and died molting to second.

No. 1309 a.-Tume 18, grub hatched since yesterilay put into box. July 29, half corerefl with mites, which prevent its growth. August 9, sickly, with many mites. August 14, died without molting to second.

Eggs devoured by wireworn and Staphylinid larve.-Occasional loss of eggs was experienced in experimental jars from wireworms (Monocrepidius sp., undetermined) and from larve of a small Staphylinid beetle, introduced into the earth with manure. The following extracts from notes give specific cases: 
Vo. 1032e--September 2t, six eggs, laid since September 17, put over damp earth in a box. September 25, tro eggs missing, and a wixerrorm present, eating a. third.

No. 986.-August 14, ont of nine eggs, laid August 9-11, placed in artificial cells in earth, two were destroyed by Staphylinid larve, which occupied the cavities where eggs bad been.

\section{LITRRATURE CITED.}

(1) Bцатсниет, W. S.-1910. Lachnostema (pp. 958-980, fig, 3, pl. 5). In The Coleoptera or Beetles Known to Occur in Indiana.

(2) Diser, J. Sydney.-1916. Rept. of the Asst. Supt. of Agr. on the Ent. and Myc. Work Carried Out During the Season Under Review. In Rept. on the Dept. of Agr., Barbados, 1914-15 (pp. 38-41).

(3) Chitrenden, F. H.-1909. Insects Injurious to Vegetables (lit. pp. 73-78, fig. 3).

(1) Daris, JoHn J.--1913. Common White-Grubs. Farmers' Bull.' 543, U. S. Dept. of Agr. (pp. 20, fig. 12).

(5) Davrs, Jokn J.-1916. A Progress Report on White-Grub Investigations. In Jour. of Econ. Ent., vol. 9. No. 2, 1916 (pp. 261-281 pI. 2).

(i) De CHarmor, D. D'Emmerez.-1912. Rapport sur Phytalus smithi (Arrowr) et Autres Scarabees S'Attacquant a. la Canne a Sucre a Maturice, Port-Louis, 1912 (pp. 35, pl. 10).

(7) Forbes, S. A.-1907. On the Life-History, Habits, and Eiconomic Relations of the White-Grubs and May-beetles. Bull. No. 116, Univ, of IIl. Agr. Exp. Sta. (pp. 447-480).

(8) Forbes, Strephen A.-1916. A General Survey of the Maybeetles (Phyllophaga) of Illinois. Bull. No. 168, Univ. of III. Agr. Exp. Sta. (pp. 215-257).

(9) Girault, A. A., AND Dodd, A. P.-19.15. The Cane Grubs of Australia. Bull. No. 2, Div. of Ent., Bu. of Sugar Exp. Stations, Queensland (pp. 60).

(10) Goot, O. ViN DER-1915. On Certain Beetle Larvæ Found in Sugar Plantations (text in Dutch). Med. Proefstation voor de Jara Suikerindustrie, pt. 5, No. 10, Soerubaia, (pp. 60, fig. 13).

(11) JARvis, E.-1916. Notes on Insects Damaging Sugar Cane in Queensland. Bull. No. 3, Div. of Ent., Bu. of Sugar Exp. Stations, Queensland (pp. 48, fomr plates).

(12) JoHnston, JoHN R.-1915. The Green Muscardine (Metarr- 
hizium anisopliœ) In The Entomogenous Fungi of Porto Rico, Bulletin No. 10 of the Board of Comm. of Agr. of P. R. (pp. 26-28).

(13) Fulagin, N. M.-1913. The Principal Insect Pests of Field Crops in European Russia for the Last Twenty Years (text in Russian). In The Year Book of the Dept. of Agr, of the Central Board of Land Administration and Agrieulture, St. Petersburg, VI, 1913 (pp. 585-638, pl. 1).

(14) Legrmans, S.-1915. De Cassave-Oerets (The Gassara Grubs). Dept. Nijyerheid, Landbouw en Handel. Med. van het Laboratorimm roor Plantenziekten, No, 13, Buitenzorg (pp. 118, pl. 7).

(15) Lmat, Chis. W., and Mutchler, A. J.-1914. A Preliminary List of the Coleoptera of the West Indies as Recorded to January 1, 1914. Bulletin of the Am. Mus. of Nat. Hist. rol. 33, art. 30, pp. 391-493.

(16) Moore, W. H. B.-1916. General Report on Insect Pests (of Cane) for the Year 1915. Rept. to Messrs. Booker Bros., McConnell \& Co., Ltd., and Messrs. Curtis, Campbell \& Co., Demerara (pp. 8).

(17) Northrup, Zate.-1914. A Bacterial Disease of June Beetle Larvæ, Lachnosterna spp. Tech. Bull. No. 18, Mich. Agx. Coll. Exp. Sta. (pp. 37, twenty-two figs.).

(18) NowbLE, W.-1915. Two Scoliid Parasites on Scarabaeid Larva in Barbados. In Ann. of Applied Biology, vol. 2, No. 1. (pp. 46-57, pl. 1).

(19) Patrensor, Wir. H.-1912. Rept. on the Agr. School, St. Vincent. In Reports on the Botanic Station, Agr. School, eto, St. Fincent, 1910-11 (pp. 19-24).

(20) Rnex, Chas. V.-1869. The White-Grub. In First Report of the Missouri State Fintomoligist on the Insects of Missouri (pp. 156-159).

(21) RnEY CHas. V.-1874. The Unadomed Tiphia or White-Grub Parasite. In Sixth Report of the Missouri State Entomologist on the Insects of Missouri (pp. 123-126).

(22) SHEPAERD, F. R--1916. Work Connected with Insect and Fungus Pests and Their Control. In Rept. of the Agr. Dept., St. Kitts-Neris, 1914-15 (pp. 15-16).

(23) SMYTr, EUGENE G.-1915. Report of Worls at the South Coast Laboratory. Third Report of the Board of Comm. of Agr. of Porto Rico ( $p$ p. 40-53).

(24) SMYTH, EugENe G.-1916. Report of the South Coast Labora- 
tory. Fourth Report of the Board of Comm. of Agr. of Porto Rico (pp. 45-50, with life-cycle tables).

(25) STEVENSON, JoHN A.-1916. Work with the Green Muscardine in Report of the Pathologist. In Frourth Report of the Board of Comma. of Agr. of Porto Rico (pp. 34-35).

(26) Tgurany, H. A.-1916. Work Connected with Insect and Fungus Pests and Their Control. In Report on the Botanic and Experiment Stations, Antigua, 1914-15 (pp. 20-22).

(27) Tin Dine, D. L.-1911. Third Report of the Entomologist. In Year book of the Association of Sngax Producers of Porto Rico, 1910-11 (pp. 43-57).

(28) VAN DINe, D. L.-1912. Report of the Entomologist. In Second Annual Report of the Exp. Sta. of the Sugar Producers' Association of Porto Rico (pp. 15-22).

(29) VAN DINe, D. L.-1912. Progress Report on Introductions of Beneficial Parasites into Porto Rico. In First Report of the Board of Comm. of Agr. of Porto Rico (pp. 31-47).

(30) VAN Dine, D. L.-1913. The introduction of Parasites of May= Beetles into Porto Rico. In Second Report of the Board of Comm. of Agr. of Porto Rico (pp. 36-48).

(31) VAN Dine, D. L.-1913. Report of the Entomologist (with list and bibliography of Porto Rican sugar-cane insects). In Third Report of the Porto Rican Sugar Producers' Exp. Sta. (pp. 25-46).

(32) VAssuctev, I. V.-1914. Short Notes on Anisoplia austriaca Herb. and Methods of Fighting It (in Russian). In Memoirs of the Burean of Entomology of the Scientific Committee of the Central Board of Land Administration and Agr., St. Pe. tersburg, VII, No. 2 (pp. 36, fig. 20, colored pl. 2):

(33) WASHBurN, F. L.-1908. Destruction of lawns by the WhiteGrub. Cireular of Information No. 11, Office of State Fntomologist, Minnesota (pp. 2, fig. 4).

(34) Wolcotr, George N.-1913. Report on a Trip to Demerara, Trinidad and Barbados during the Winter of 1912. In Third Report of the Sugar Producers' Association Exp. Sta. (pp. 47-68).

(35) Wolgote, GEoraE N.-1914. Notes on the Life-History and Ecology of Tiphia inornata Say. In Jour. of Econ. Ent., vol. 7, No. 5 (pp. 382-389).

(36) Worootr, Grorge N-1915. Report of the Traveling Entomologist. In Third Report of the Board of Comm. of Agre. of Porto Rico (pp. 25-40). 


\section{EXPLANATION OF PLATES.}

PLAILE II.

Fig. 1.-Banana tree stripped of foliage by May-beetles, chiefly by Phyllophaga vandinei n. sp.

Fig. 2.- Leaf of a coconut palm injures by the feeding of adults of Phyllophagu portoricensis n. sp.

Fig. 3.-Salcilla tree (Schronkia portoricensis), a wild species abundant in the Guámica district and whose foliage is much relished by adults of $P$. vandinei; adaptable for use in collecting the beetles in large numbers by shaking.

Fig. 4.-A bushel of adults of $P$. vandinei collected in one evening by nine boys in a cane field at Santa Rita, near Guánica.

\section{Pliate IIT.}

Fig. 1.-Phyllophaga vandinei n. sp., eggs lying over soil, $\times 2$ (the elongate egg marked with an " $\mathrm{x}$ " is that of Pyrophorus huminosus IJliger, an Blaterid whose larva is̀ predaceous on white-grubs).

Fig. 2.-Phyllophaga vendinei n. sp. grubs just hatehed from eggs, $x 3$.

F'ig. 3.-Phyllophaga vandinei n. sp. gxubs at end of first instar, $x 2$.

Fig. 4.-Phyllophaga vandinei n. sp. gxub at ead of second instar, $\times 2$.

Fig. 5.-Phyllophaga vandinei $\mathrm{n}$. sp. grub in act of molting to third instar, $\mathrm{x} 5$.

Fig. 6.-Phyllophaga vandine $\mathrm{n}$. sp. grub at beginning of the third instar, $x 2$.

Fig: 7.-Phyllophaga vandinei n. sp. mature grub (a.t end of third instar), x 2 .

Fig. 8.-Phyllophaga vandinei n. sj. prepupa (grub about to pupate), $\times 2$.

F'ig. 9.-Phyllophaga vandinei n. sp. pupa, side view, showing shed larval skin, $\times 2$.

Fig. 10.-Phyllophaga vandinei n. sp. pupa at point of issuing of adult, $x 2$.

PLATE IV.

Fig. I.-Phyllophaga vandinei in. sp., pupa, ventral view, $\times 2$.

Fig. 2.-Phyllophaga vandinei n. sp. pripa, dorsal view, $\times 2$.

Fig. 3.-Phyllophaga vandinei $\mathrm{x}$. sp. male adult, $\times 2$.

Fig. 4.-Phyllophaga portoricensis n. s]., female adult, $\times 2$.

Fig. 5.-Phyllophaga portoricensis n. sp. male adult, $\times 2$.

Fig. 6.-Phyllophaga vandinei n. sp. adult. just issued from pupa, $\times 2$.

Fig. 7.-Phyllophaga vandinei, n. sp. adult attacked by Meterrhizinm, dorsal view, $\times 2$.

Fig. S.-Phyllophaga vandinei n. sp. same, side view, $\times 2$.

Fig. 9.-Phyllophaga vandinei $n$. sp. larva infesten with Metamhizinm, $\mathrm{x} 2$.

\section{Plate $r$ :}

Fig. 1.-Phyllophaga vandinei i. sp. heads of grubs in first instar, $\mathbf{x} .0$.

Fig. 2.- Phyllophaga vandinei 1 . sp. head of a grub in second instar, $x 10$. 
Wig. 3.-Phyllophaga vanaine $u$. sp. head of a grub in third instar, $x$ 10.

Fig. 4.- Phyllophaga guanicana n. sp., male genitalia, $\mathrm{x} 6$ (with mm. seale).

Fig. 5.-Phyllophaga citri n. sp., male genitalia, x 6 .

Fig. 6.-Phyllophaga vandine ${ }^{2}$ n. sp., male genitalia, $x 6$.

Fig. 7.--Phyllophaga portoricensis n. sp., male genitalia, $x 6$.

Fig. 8.-Phyllophaga citri n. sp., female genitalia, x $51 / 2$ (reutral rier).

Fig. 9.-Phyllophaga portoricensis n. sp, egg in pit made by the ovipositor, $x$.

Fig. 10.-Phyllophaga portorioensis, female gemitalia, $\times 5 \frac{1}{2}$ (ventral riew).

\section{Plate VI}

Fig. 1.-Black birds (Hologuiscalns brachypterus) following a plow in cane field at Santa Rita to pick up white grubs.

Fig. 2.-Phyllophaga guanicana n. sp., egg. Iying ovex soil, x 2 .

Fig. 3.-Phyilophage guanicana n. sp., swollen eggs in the aatural pits, $x 6$.

Fig. A.-Phyllophaga granicana n. sp., grub at end of second histar, $x 2$.

Fig. 5.-Phyllophaga guanicana n. \$p, matuxe grub (end of third instar), $\times 2$.

Fig. 6.-Phyllophaga guanicana n. sp., male ađult, $\times 2$.

Fig. $\vec{i}$.-Phyllophaga gna:icana n. sp., female adult, $x 2$.

F゙ig. 8.-Phyllophaga citri $n$. sp., male adult, $\times 2$.

Fig. 9.-Phyllophaga citvi n. sp., female adult, $x 2$.

PLATE VII.

Tig. 1.-Phytalus insularis घ. sp., eggs lying over soil, $\mathrm{x} 3$.

Fig, 2.-Phytalus insularis n. sp., grubs at end of third instar, $\times 3$.

Fig. 3.--Phytalus insularis a. sp., paix of adults, $x 3$.

Fig. 4.-Phytalus insularis n. sp., head of adult below that of Phyllophaga vandinei to show comparative size, $\times 6$.

Fig. 5.-Phytalns insularis n. sp., anal aspect of female adult (with scale in milli meter's to show size), $\times 6$.

Fig. 6.-Phytalus insularis n. sp. anal aspect of male adult, $\mathrm{x} 6$.

Fig. 7.-Cryptomeigenia aurifacies Walton, adult (right) and pupal case (left), $\times 3$.

Fig. 8.-Tiphia inomato Say, adult male at right, adult female at left ores the cocoon.

Plate VITr.

Life-cyeles of iudividual females of Phyllophaga vandinei n. sp. in Porto Rico.

\section{PIATTE IX}

Egg-laying records of individual females of Phyllophaga vandinei n. sp. 
Plate II-Porto Rican SRelolonthids.

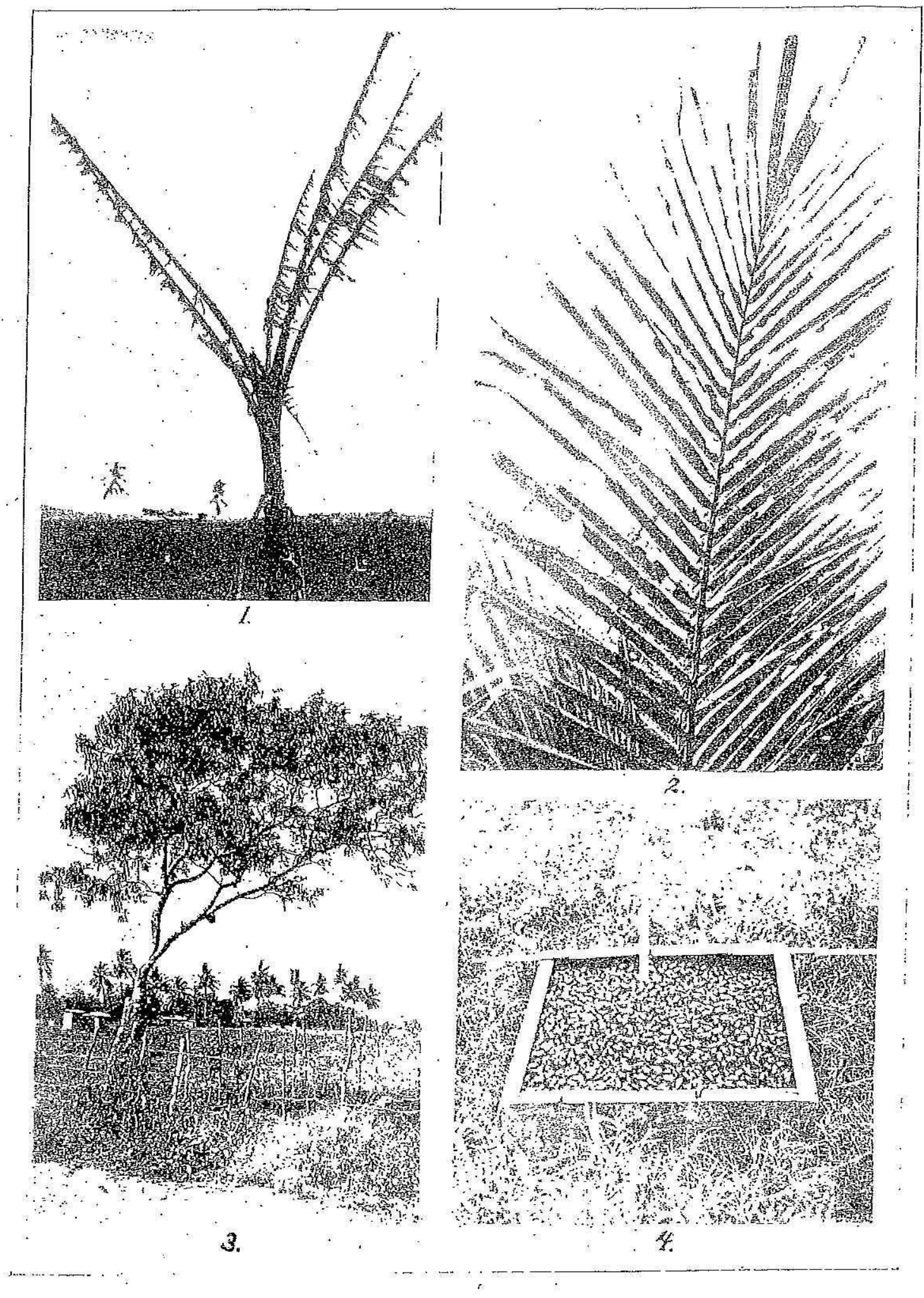


Plate IIr. $\bar{P}$ orto Rican Melolonthids.

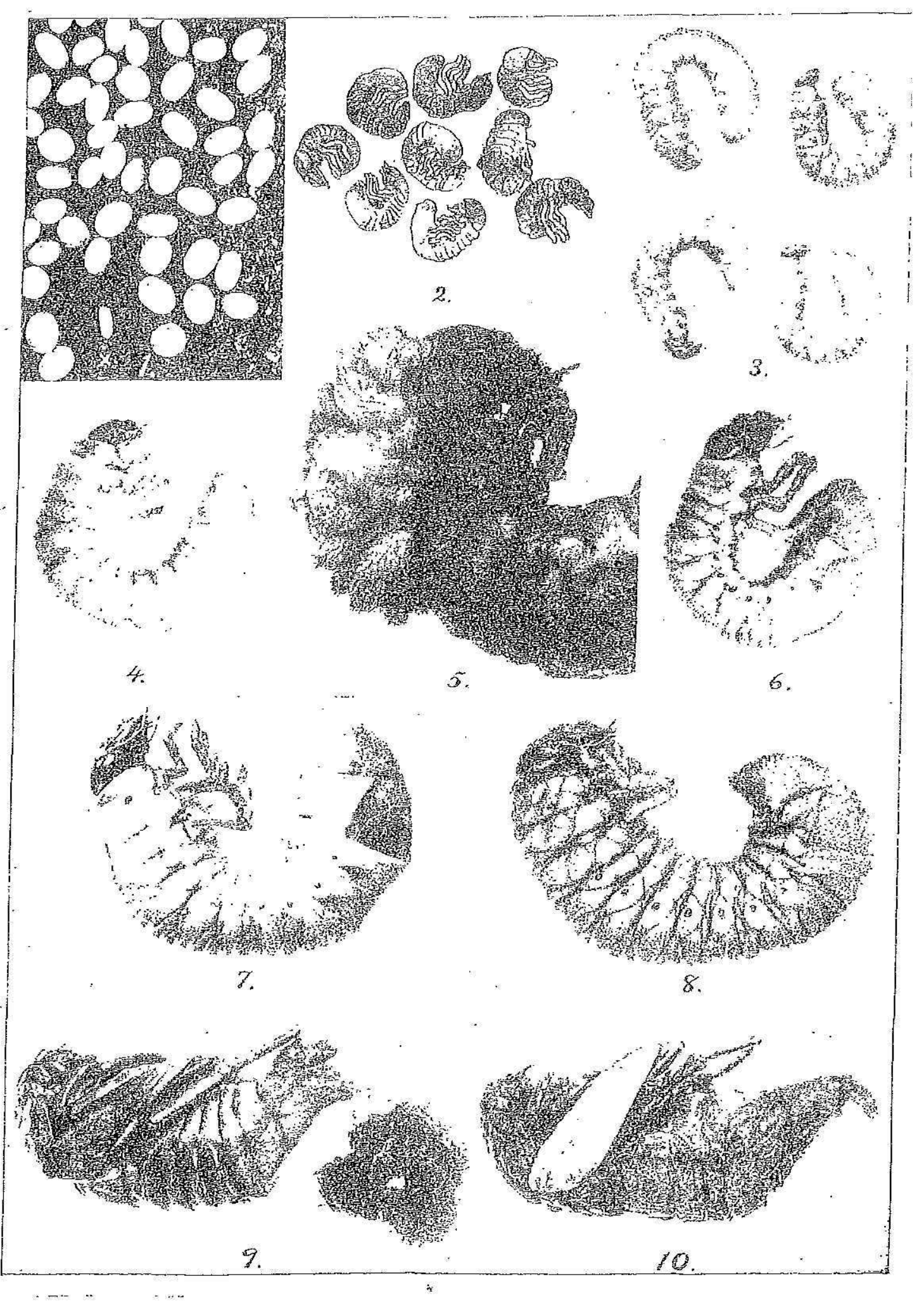


Plate TV.-Porto Rican Melolonthids.

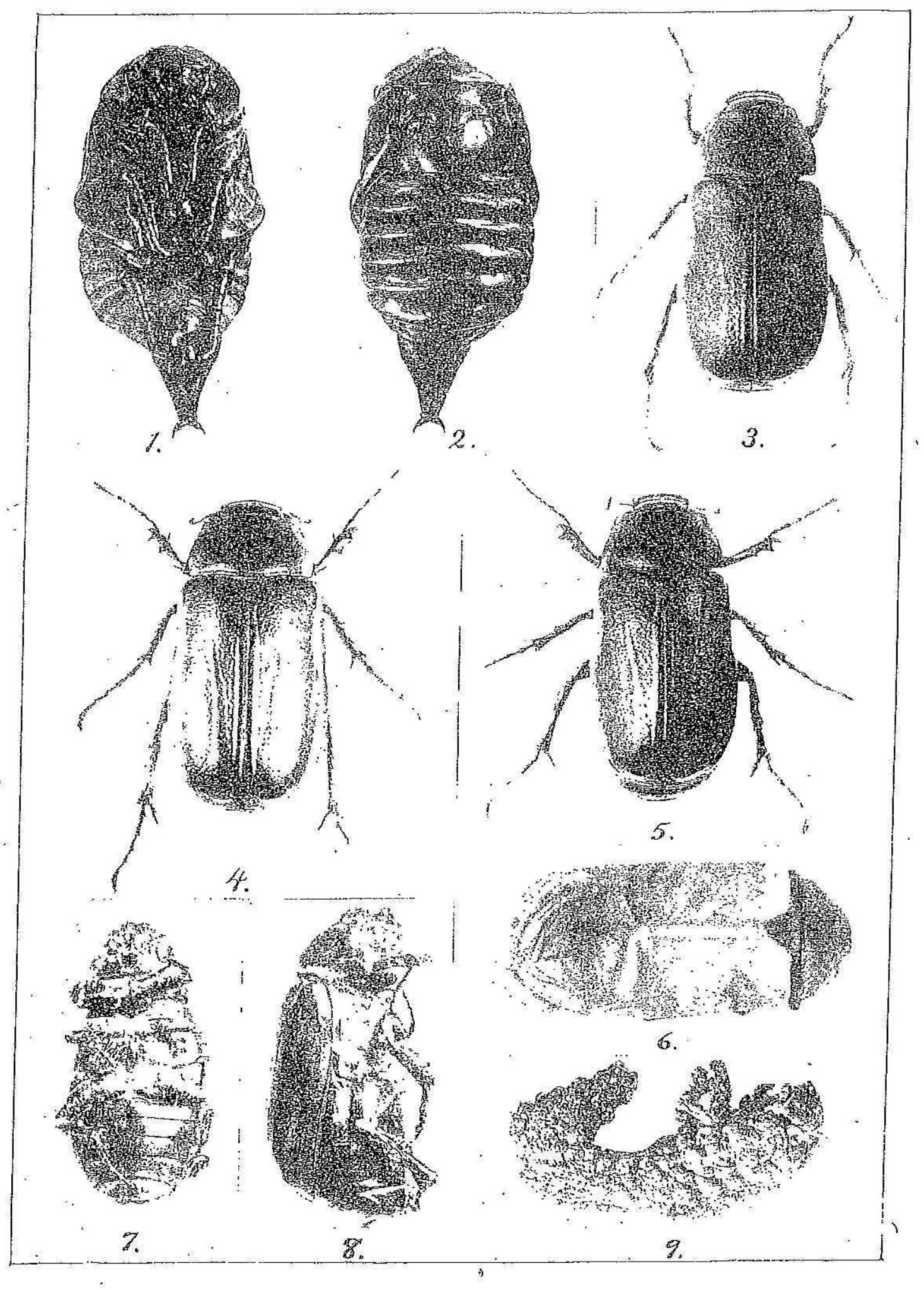


Plate V.-Porto Rican Melolonthids.

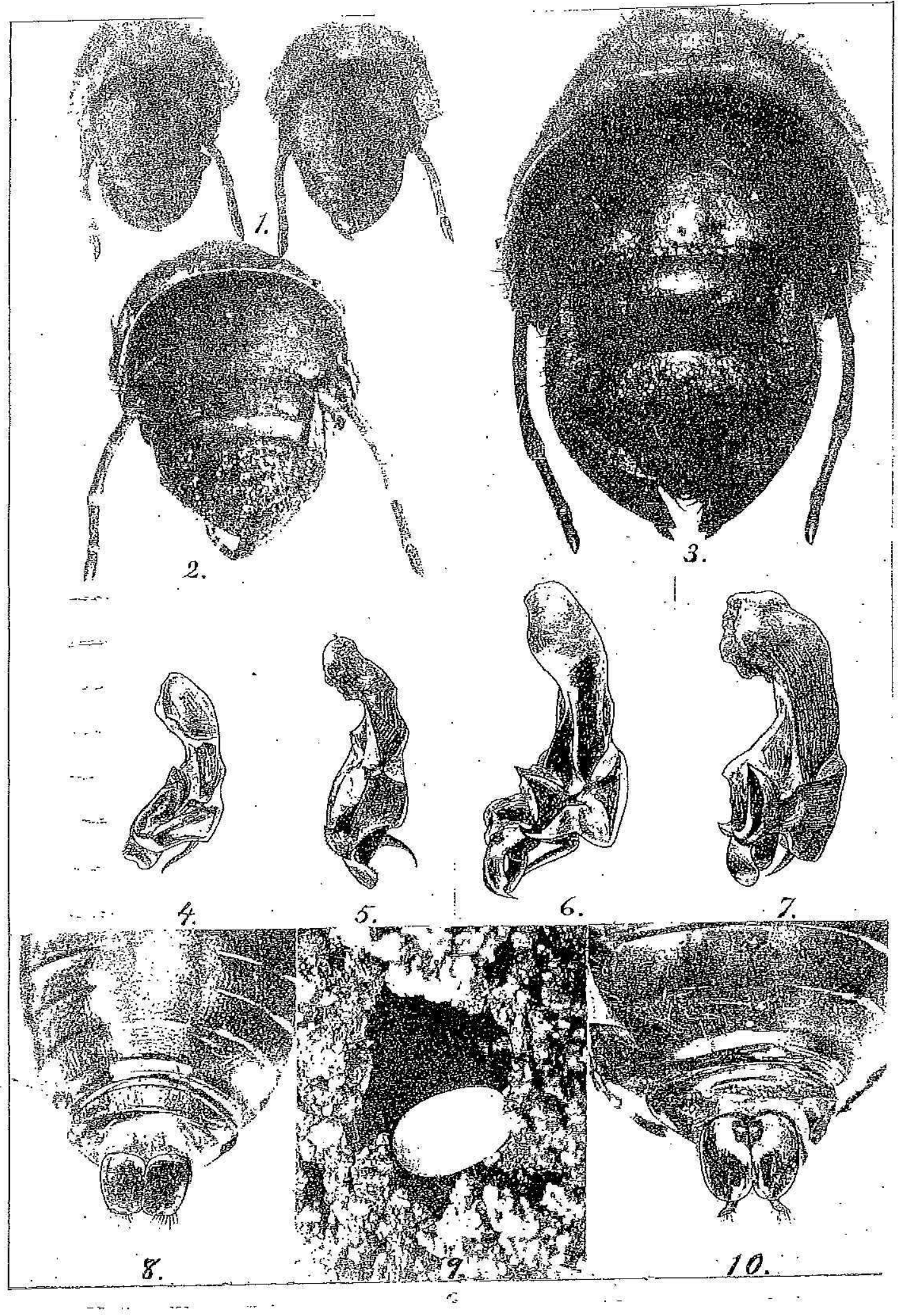


Plate VI-Porto Rican Nelolontinids.

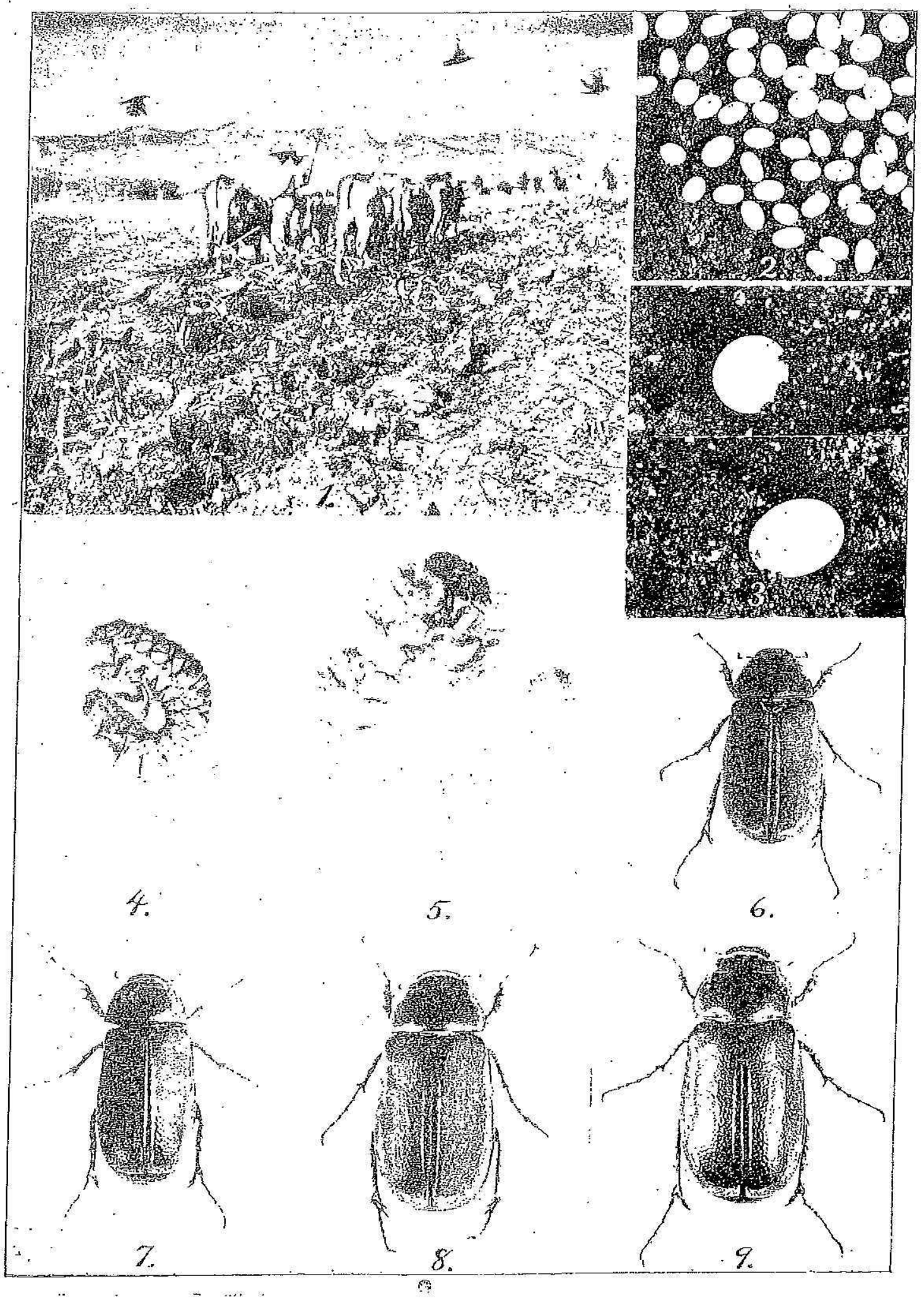




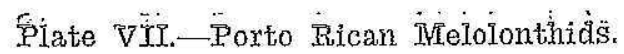

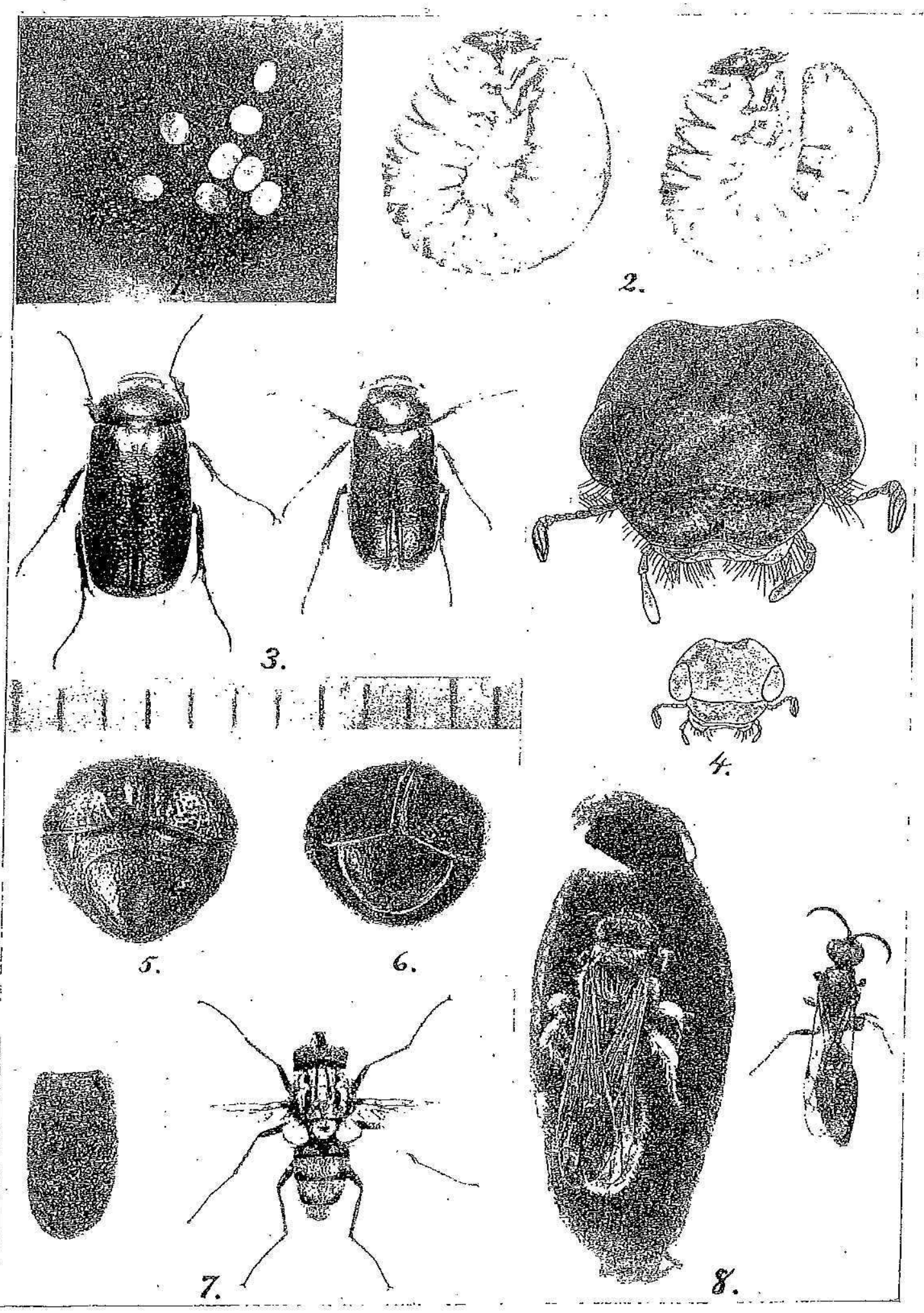




\section{Y}

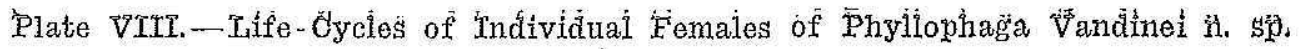
in Porto Rico.

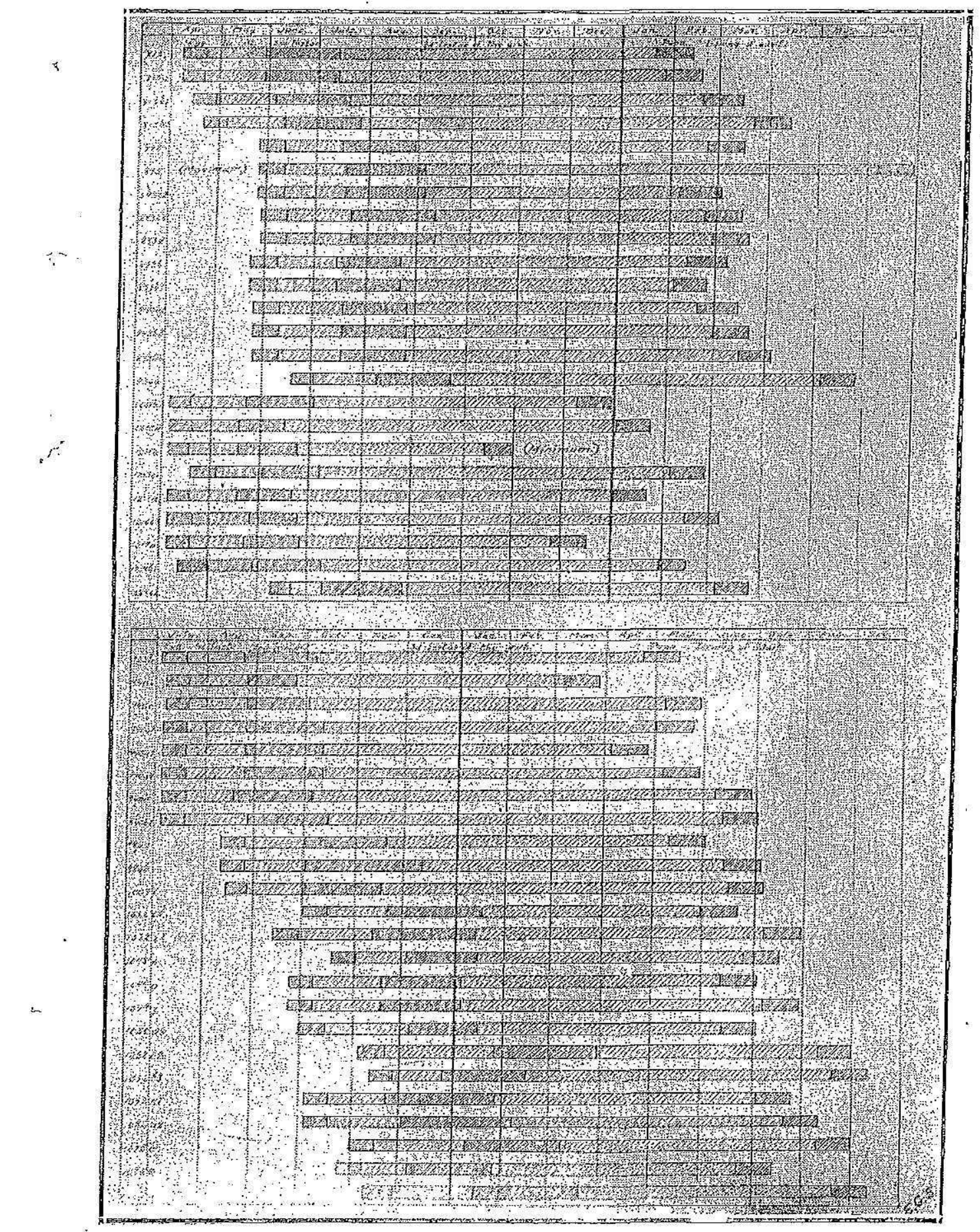


Plate IX--Egg-Laying Records of Individual Femaīes of Phyllophaga Vandinel.
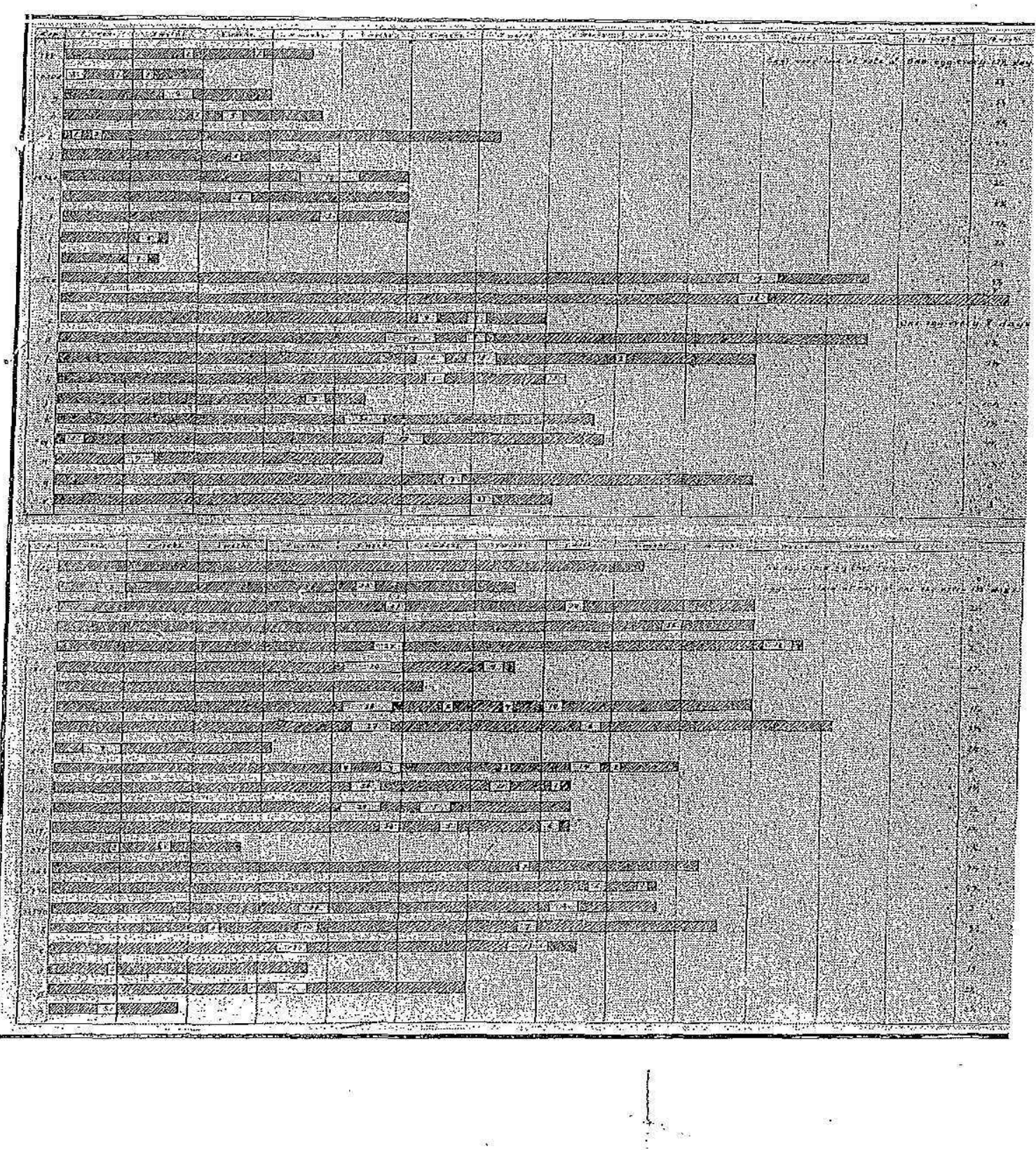